OPEN ACCESS

Edited by:

Shin Murakami,

Touro University California, USA

Reviewed by:

Gil Atzmon,

Albert Einstein College of Medicine,

USA

Anatoliy I. Yashin,

Duke University, USA

Mark A. McCormick,

Buck Institute for Research on Aging,

USA

*Correspondence:

Emanuele Pelosi

pelosie@mail.nih.gov

Specialty section:

This article was submitted to

Genetics of Aging,

a section of the journal

Frontiers in Genetics

Received: 22 July 2015 Accepted: 24 September 2015

Published: 15 October 2015

Citation:

Pelosi E, Forabosco A and Schlessinger D (2015)

Genetics of the ovarian reserve.

Front. Genet. 6:308.

doi: 10.3389/fgene.2015.00308

\section{Genetics of the ovarian reserve}

\author{
Emanuele Pelosi ${ }^{1 *}$, Antonino Forabosco ${ }^{2}$ and David Schlessinger ${ }^{1}$ \\ ${ }^{1}$ Intramural Research Program, National Institute on Aging, National Institutes of Health, Baltimore, MD, USA, ${ }^{2}$ Genomic \\ Research Centre, Cante di Montevecchio Association, Fano, Italy
}

Primordial follicles or non-growing follicles (NGFs) are the functional unit of reproduction, each comprising a single germ cell surrounded by supporting somatic cells. NGFs constitute the ovarian reserve (OR), prerequisite for germ cell ovulation and the continuation of the species. The dynamics of the reserve is determined by the number of NGFs formed and their complex subsequent fates. During the reproductive lifespan, the OR progressively diminishes due to follicle atresia as well as recruitment, maturation, and ovulation. The depletion of the OR is the major determining driver of menopause, which ensues when the number of primordial follicles falls below a threshold of $\sim 1,000$. Therefore, genes and processes involved in follicle dynamics are particularly important to understand the process of menopause, both in the typical reproductive lifespan and in conditions like primary ovarian insufficiency, defined as menopause before age 40 . Genes and their variants that affect the timing of menopause thereby provide candidates for diagnosis of and intervention in problems of reproductive lifespan. We review the current knowledge of processes and genes involved in the development of the OR and in the dynamics of ovarian follicles.

Keywords: ovarian reserve, reproduction, reproductive lifespan, menopause, folliculogenesis

\section{INTRODUCTION}

The growing trend in all contemporary societies for childbearing later in women's lives, accompanied by the increasing use of assisted reproduction technology, make the term ovarian reserve (OR) increasingly prominent in medical and scientific literature. Coined more than 25 years ago by Navot et al. (1987), it occurs in at least 1,500 papers currently in PubMed, with an exponentially increasing prevalence. However, the concept of OR is rarely defined, and varies in its usage in different contexts. In current clinical literature OR unambiguously signifies the number and quality of the follicles remaining in an ovary at any given time (Broekmans et al., 2006) or a woman's reproductive potential as a function of the number and quality of her remaining oocytes (American College of Obstetricians and Gynecologists (ACOG), 2015). By contrast, the research literature considers that the mammalian ovary contains two functional pools: a pool of resting or non-growing follicles (NGFs) and another of growing follicles. A resting follicle is "primordial," comprised of an oocyte surrounded by a single layer of flattened somatic pre-granulosa cells and arrested in the diplotene/dictyate stage of meiotic prophase I. Such a follicle continues to be quiescent throughout life unless it is lost by atresia or recruited for maturation. By contrast, the growing follicles have been activated to various stages of maturation in the process now generally called folliculogenesis. The "activated" pool includes primary, secondary, preantral, antral, and preovulatory or Graafian follicles (Gougeon, 1986). Several other terms have been proposed, including "ovulatory potential" (Findlay et al., 2015) or "dynamic reserve" (Monniaux et al., 2014), for the growing follicle pool that supports normal folliculogenesis and can potentially be ovulated or induced to maturity (e.g., in assisted conception). 
In this discussion, adopting the preponderant view in the field, OR is considered as the size of the NGF pool in a woman's two ovaries at any given age. This is the most valid measure of female reproductive lifespan.

However, the assessment of human OR remains technically problematic. Especially because follicles are unevenly distributed in the ovarian cortex (van Wagenen and Simpson, 1965; Sforza et al., 2003), invasive and partially destructive methods, such as ovarian biopsy, do not yield a reliable estimate of the OR (Lambalk et al., 2004; Lass, 2004), and direct in vivo counting is currently not possible.

A number of non-invasive procedures, including determination of ovarian volume, antral follicle count (AFC), and certain serum markers, have been proposed singly and in combination to assess the OR for individual women (American College of Obstetricians and Gynecologists (ACOG), 2015), but none of these procedures has been shown to be directly related to the size of the OR (Findlay et al., 2015). It has been observed that these procedures are a measure of "ovarian response" rather than a measure of OR (Nelson, 2014).

The most reliable route to assess the OR is to remove ovaries and carry out histomorphometry-based follicle counts in serial tissue sections of the entire ovaries (Tilly, 2003). To date, using this method on tissues retrieved post-mortem or post-oophorectomy, there have been six studies that estimated the OR in females at various chronological ages. Two of these studies have evaluated the OR in the phase of its formation (Block, 1953; Forabosco and Sforza, 2007), and four have focused on OR dynamics from birth to menopause (Block, 1952; Richardson et al., 1987; Gougeon et al., 1994; Hansen et al., 2008). These studies have shown that the OR increases dramatically from 15 weeks of post-conception (wpc) until the 34th wpc, and thereafter remains constant, with an average of about 680,000 NGFs, until at least 2 years after birth (Block, 1953; Forabosco and Sforza, 2007; Hansen et al., 2008). As for the OR in postnatal life, before puberty quantitative data are scanty. There are no data between 2 and 7 years, and from 7 to 12 years the measures show considerable variability (Block, 1952; Hansen et al., 2008). The available data indicate a limited decrement from early postnatal numbers. An average of $\sim 460,000$ of follicles remains around puberty (age 12-14; Block, 1952; Hansen et al., 2008). Thereafter, the OR will decline continuously until menopause initiates at $<1000$ NGFs (Block, 1952; Richardson et al., 1987; Gougeon et al., 1994; Hansen et al., 2008).

The changing dynamics of $\mathrm{OR}$ are the consequence of two opposing processes that involve complex genetic and environmental factors: the formation of new NGFs and the recruitment of NGFs from the OR for maturation or atresia (Kerr et al., 2013). During this scenario, newly formed NGFs are maintained for various lengths of time during the reproductive lifespan (Adhikari and Liu, 2009; Reddy et al., 2010).

In summary, the size of the human OR during life is not constant. After a first prenatal step in which the OR is established, the size of the OR is kept constant during an intermediate perinatal step and then progressively decreases to values that no longer support ovulation (Pelosi et al., 2015).

The life course of ovarian function once the OR is established thus represents an unusual case in which aging has two components. The usual stochastic decline of function and activity seen in all physiological systems certainly occurs-as seen in the progressive loss of quality of oocytes (Henderson and Edwards, 1968; Tarín et al., 1998); but the major force is the programmed monthly recruitment of oocytes that progressively depletes the OR. In other words, the decline in the size of the OR drives reproductive aging (i.e., toward menopause). Menopause ensues when regular recruitment decreases follicle numbers below a threshold. This process is at least partially genetically determined. Thus, although it has much sharper timing in a population of women than other age-related declines, the dynamics of the reserve and the timing of menopause can be changed by mutations or environmental factors that alter the size of the initial reserve or slow the rate of recruitment/atresia.

The effects of prenatal and postnatal environmental factors on OR have recently been updated (Richardson et al., 2014), in this review we consider the genomic factors that influence OR dynamics during prenatal and postnatal life.

Studies have found many genes affecting OR: no single dominant gene has been identified as responsible for the life course of OR. We first consider the genomics of formation of new NGFs with the establishment of the OR, and then turn to the genomics of the recruitment of NGFs from the OR for maturation and atresia. We reference available data on human instances of reduced OR, and especially primary ovarian insufficiency (POI); but the vast majority of studies have been performed on animal models. There are obvious differences between the evolutionarily distant rodent models and human-including the time scale, the mouse estrus cycle, and some differences in gene usage noted in the text below. Nevertheless, the available comparative developmental and genetic data are consistent with very similar overall formation and fate of the OR.

\section{GENOMICS OF THE ESTABLISHMENT OF THE OVARIAN RESERVE}

In every mammalian species, the OR is formed during definitive ovarian histogenesis, the last phase of ovary organogenesis (Ottolenghi et al., 2004), by a coordinated series of processes collectively referred to as follicular endowment (Hirshfield, 1991). NGF endowment begins with the formation, commitment, migration, and colonization of the gonad by a founder population of primordial germ cells (PGCs). After the development of the bipotential gonad, and female sex determination (see She and Yang, 2014), definitive ovarian histogenesis occurs, and the size of the OR is consolidated during follicle formation, now called follicular assembly (Skinner, 2005; Pepling, 2012).

\section{Genes Involved in Formation, Migration, and Gonad Colonization of PGCs}

The somatic compartment and PGCs develop in different microenvironments, correlated with their idiosyncratic identities. During gastrulation $-3 \mathrm{wpc}$ in humans - a small population of PGCs develops in the extra-embryonic compartment, specifically at the base of the allantois in the endoderm of the dorsal wall of the yolk sac (Ginsburg et al., 1990). Subsequently, PGCs start 
to migrate to their final destination, the gonad, a process that is completed $\sim 6-7$ wpc (Fujimoto et al., 1977; Kurilo, 1981). It is during this migration that PGCs start to proliferate, and they continue to multiply during the colonization of the gonad (Baker, 1963).

In mouse, the process is relatively compressed in its shorter lifespan, with PGCs developing starting at E6.25, migrating at $\sim \mathrm{E} 8.5$, and completely installed in the genital ridges by $\sim \mathrm{E} 10.5$ (Saitou and Yamaji, 2012).

Studies in the mouse have revealed some of the most critical signals for PGC specification, migration and proliferation. PGC specification is dependent on BMP signaling from the extraembryonic ectoderm (Pelosi et al., 2011). Indeed, in Bmp4 $4^{-/-}$ embryos PGCs fail to complete migration, and $B m p 4^{+/-}$ovaries show a reduced or absent population of PGCs (Lawson et al., 1999). Furthermore, deletion of other members of this family, such as $B m p 2$ and $B m p 8 b$, and of downstream mediators of the BMP pathway like Smad1 and Smad5, produced similar phenotypes (Ying et al., 2000; Chang and Matzuk, 2001; Tremblay et al., 2001; Ying and Zhao, 2001). Subsequently, Blimp1 expression is required to maintain PGC identity and inhibit differentiation into the mesodermal cell lineage (Ohinata et al., 2005).

Germ cells express important survival factors very early during and following their specification. They include the pluripotencyrelated Oct4. Oct4 is necessary for embryo development and the formation of the pluripotent inner cell mass (Nichols et al., 1998). Conditional deletion of Oct4 in PGCs also resulted in early apoptosis and resultant lack of germ cells in the adult ovary (Kehler et al., 2004).

Nanos genes are also important for specification and migration of PGCs. In Drosophila ablation of maternally-derived Nanos1 leads to failure of PGC migration (Kobayashi et al., 1996). By contrast, deletion of mouse Nanos1 did not affect germ cell development (Haraguchi et al., 2003; and Nanos2 is expressed only in male PGCs). However, ablation of Nanos 3 caused defects in mouse PGC migration and proliferation, leading to sterility in both males and females (Tsuda et al., 2003).

Coordinated expression of Kit receptor and its ligand Kitl, encoded at the white spotting (W) and steel ( $\mathrm{Sl}$ ) loci, respectively, is indispensable for the survival, migration, proliferation, and overall proper establishment of ovarian PGC for future follicle assembly (Thomas and Vanderhyden, 2006). Kit is expressed in mouse germ cells starting at E7.5 during their migration to the ovary, while its ligand Kitl is expressed in somatic cells along the migratory route (Besmer et al., 1993). Several mutant alleles at the $\mathrm{W}$ or Sl loci have been described, and the type of mutation determines the severity of the phenotype, ranging from reduction of the number of PGCs reaching the gonad to reduced developmental capability of the germ cells (Russell et al., 1948; Reith et al., 1990; Buehr et al., 1993; Bedell et al., 1995). The mutant steel panda at the Sl locus causes a pronounced decrease in the size of the OR at birth, along with arrest of the remaining follicles at the primordial stage (Huang et al., 1993). By contrast, the Wv mouse variant, caused by a point mutation in the conserved ATP binding domain, produces a phenotype reminiscent of POI in women (Smith et al., 2012); the size of the OR in these mice is severely compromised at birth and exhausted by 2 months, and the mice display elevated gonadotropin levels, reduced estrogen and progesterone levels, and decreased bone density (Smith et al., 2012).

Factors involved in germ cell proliferation are also critical for the formation and maintenance of the initial population of germ cells. Pin 1 affects cell cycle regulation, and its ablation in mice caused fertility defects due to prolongation of the cell cycle with resultant slower proliferation. The features included diminished numbers of gonocytes and oocytes during embryonic development (Atchison et al., 2003). Similarly, deletion of Pog, which is involved in germ cell proliferation, led to sterility, with a smaller pool of germ cells at birth and no follicles in the adult ovary (Agoulnik et al., 2002).

\section{Genes Involved in Definitive Ovarian Histogenesis}

Once the ovary has been formed and germ cells are committed to the female fate, ovarian development moves to the last phase of organogenesis (Ottolenghi et al., 2004), the definitive ovarian histogenesis with establishment of the OR. This occurs with the process of follicle histogenesis or follicular assembly (Pepling, 2012), starting about postnatal day 0 (P0, birth) in mice and before $13 \mathrm{wpc}$ in human in the inner portion of the ovary, near the rete ovarii (Kurilo, 1981; Gondos et al., 1986; Sforza et al., 2003; Maheshwar and Fowler, 2008).

The solid cell mass of the bipotential gonad is progressively cleaved into elongate formations of germinal and somatic cells called "ovigerous cords" (Byskov, 1986).

The population of oogonia, derived from PGCs, expands dramatically through a series of rapid mitotic divisions with incomplete cytokinesis. This results in syncytial nests of oogonia called "germ cell nests" or "germ cell cysts." In the human fetal ovary all oogonia display similar mitotic activity (Bendsen et al., 2006) until about $10 \mathrm{wpc}$, and then the first oogonia enlarge and become primary oocytes that initiate meiotic prophase I. Preleptotene cells are found as early as 9-10 wpc (Kurilo, 1981; Gondos et al., 1986; Bendsen et al., 2006).

Initially, meiosis is strikingly asynchronous, with more and more germ cells initiating meiosis while some oogonia are still expressing stem cell markers and continuing to proliferate until at least 16 wpc (Baker, 1963; Skrzypczak et al., 1981; Kerr et al., 2008). After the preleptotene stage, the primary oocytes rapidly proceed through the subsequent stages of prophase of the first meiotic division-i.e., leptotene, zygotene, and pachytene, reaching diplotene and the "resting" or "arrested" stage at which meiosis is blocked with the nucleus filled with decondensed chromatin. This state is also called "dictyate."

We next discuss genes and processes within the oocyte that act in assembly of the primordial follicle pool.

\section{Genes Involved in Germ Cell Survival, Meiosis, and DNA Damage Repair}

Study of an anti-apoptotic $B c l-x$ hypomorphic mouse model showed that PGC migrated to the genital ridge by E12.5 but were lost by apoptosis by E15.5, suggesting the importance of $\mathrm{Bcl}-\mathrm{x}$ 
for germ cell survival (Rucker et al., 2000). However, deletion of $B c l-x$ in postnatal oocytes did not affect the size of the OR or growing follicles, so that its specific action is apparently limited to embryonic development (Riedlinger et al., 2002).

In addition to apoptosis, autophagy is important in regulating oocyte and follicle development. Ablation of either of two autophagic factors, Atg7 and Becn1, led to comparable loss of follicles by P1 (Gawriluk et al., 2011).

Connexin 43, encoded by Gjal, is one of the proteins forming the gap junctions that permit passage of molecules between cells in the ovigerous cords. The phenotype of $\mathrm{Gja1}^{-/-}$mice is germ cell-specific and affects both sexes (Juneja et al., 1999). The number of PGC is reduced in embryonic gonads starting from E11.5, suggesting an indispensable function of connexins in communication between cells during PGC development.

During meiosis, germ cells undergo DNA double-strand breaks for recombination that potentiates genetic diversity in progeny. Mutations in genes involved in creation and repair of doublestrand breaks negatively impact fertility and lead to POI (Pelosi et al., 2015). For example, Spo11 is required to induce doublestrand breaks during meiosis, and $S p o 1^{-/-}$female mice have a smaller OR, with germ cell defects evident by E15.5 (Romanienko and Camerini-Otero, 2000). Meiotic defects also result from deletion of two other meiosis-specific genes. Premature loss of mouse germ cells that was complete by $\mathrm{P} 4$ was seen in $M s h 4^{-/-}$ and by 2 months in Msh5 ${ }^{-/-}$ovaries (de Vries et al., 1999; Kneitz et al., 2000).

Among additional meiotic genes, $D m c 1$ encodes a protein needed for DNA strand exchange, and its deletion in mice also caused a reduction in mouse follicle numbers and follicle attendant on failure of chromosome synapsis (Pittman et al., 1998). Interestingly, both $M S H 5$ and $D M C 1$ have also been found associated with POI in women (Mandon-Pépin et al., 2008). Defective mouse chromosome synapsis also ensued when $\operatorname{Rec} 8$, a component of the cohesin complex, was ablated, causing loss of follicles by P5 (Xu et al., 2005).

A vital factor in DNA damage checkpoint control during meiosis is the ataxia telangiectasia mutated (Atm) gene, which is activated following double-strand breaks. Deletion of Atm in mice led to loss of follicles by P11 and resulted in sterility (Barlow et al., 1998). And in humans, ataxia telangiectasia, the loss-of-function mutation of $A T M$, is associated with ovarian dysgenesis with defects in PGC development (Miller and Chatten, 1967). Failure of crossover focus formation and generation of non-exchange mouse chromosomes also occurred after ablation of $L s h$, another factor involved in the maintenance of genomic stability. Again, this led to oocyte loss and lack of follicle formation (De La Fuente et al., 2006).

Cdk2 is involved more generally in cell cycle progression. It has nevertheless been found that $C d k 2$ is dispensable during mitosis, but is critical for the completion of prophase I of meiosis, and Cdk2 mutation caused complete germ cell loss by P2 (Ortega et al., 2003). A similar sterile phenotype resulted from ablation in mice of Cbep, which is involved in the regulation of the synaptonemal complex. Cbep ${ }^{-/-}$female mice were sterile and contained only a few oocytes arrested in pachytene (Tay and Richter, 2001).
Ablation of Brca1-involved in DNA damage detection and repair, as well as cell cycle arrest-is embryonic lethal in mice (Shen et al., 1998). However, Brcal heterozygous mutant mice survived, though with a reduced OR seen as early as P5; by contrast, $\mathrm{Brca} 2$ heterozygous or homozygous ovaries were indistinguishable from wild-type (Titus et al., 2013). Function of DNA repair genes, including Brcal, was shown to decrease with age, while double-strand breaks accumulated in mouse and human oocytes. Women with BRCA1 mutations were also reported to have lower OR, inferred from AMH levels (Titus et al., 2013), but others observed no change in fertility or OR (Kotsopoulos et al., 2008; Moslehi et al., 2010; Pal et al., 2010; Valentini et al., 2013; Michaelson-Cohen et al., 2014). Understanding the role of BRCA1/2 in menopause or POI is complicated by the lack of standardization in various studies, which assessed fertility or OR with various methods. In addition, several reports had few participants and stratification was not always the same. Also, the association between BRCA1/2 and fertility may depend on other factors, even though several studies have reported earlier menopause or low OR in BRCA carriers (Rzepka-Górska et al., 2006; Oktay et al., 2010; Finch et al., 2013; Lin et al., 2013; Wang et al., 2014a). As one specific possible source of discrepancies in study results, $B R C A 1 / 2$ effects may be smaller in younger women and become more clinically evident in those approaching perimenopause (an age cohort that was not included in several of the studies).

Mutations in the Fanconi anemia complex of DNA damage genes are also implicated in the control of OR. Deletion of Fanca in mice led to reduced fertility and sterility by 21 weeks of age with the total depletion of ovarian follicles (Cheng et al., 2000). A very similar phenotype was also found in $\mathrm{Fancc}^{-/-}$mice (Whitney et al., 1996); and deletion of Fancg caused comparable infertility at 21 weeks of age with a dramatic reduction in the OR (Koomen et al., 2002).

Heat shock proteins have additional functions in meiosis completion and oocyte development. Hsf1 is a maternal effect transcription factor affecting the expression of several heat shock proteins including Hsp90a, Hsp25, Hsp70.1, and Hsp105 (Metchat et al., 2009). When it was deleted in mice, meiotic defects in oocytes ensued, characterized by delayed G2/M transition, partial block of germinal vesicle breakdown, and asymmetrical division. Furthermore, $H s f 1$ was required for embryonic development, eliciting a protective response against oxidative stress in the oocyte (Bierkamp et al., 2010).

Finally, mutations in several other meiotic genes have also been identified as associated with POI in humans. Caburet et al. (2014) demonstrated mutations in STAG3 (cohesin) - thought to be involved in sister chromatid association-in a large pedigree evincing POI ("POF8" in OMIM 615723), and mice ablated for the gene were sterile. Mutation in the X-linked gene, POF1B, encoding a protein that interacts with actin filaments, causes "POF2B" (OMIM 300604; Lacombe et al., 2006); the authors hypothesized that POF1B could also function in the pairing of meiotic chromosomes, and alteration in its function could lead to drastically fewer oocytes being created. Wang et al. (2014b) found another meiotic gene, HFM1, mutated in two sisters with POI, and in another case among 69 analyzed 


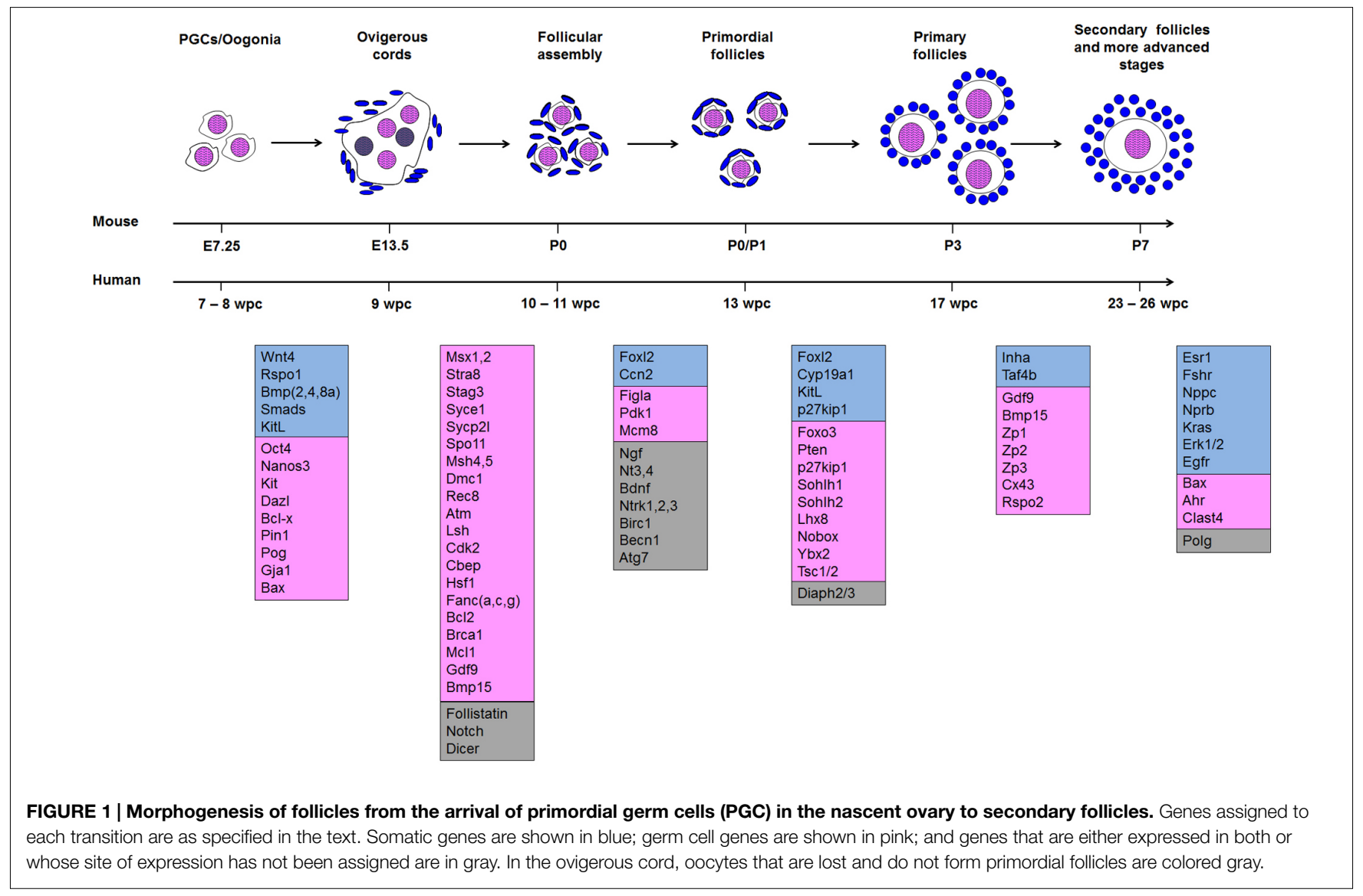

("POF9" in OMIM 615724). Mutation in SYCE1, essential for formation of the synaptonemal complex, can account for autosomal recessive POI in another family (de Vries et al., 2014).

\section{Genes Involved in Follicular Assembly}

During the progression to the dictyate state, the ovigerous cords are carved into clusters of germinal and somatic cells that give rise to the NGFs (Zamboni et al., 1980). The nascent NGFs emerge when the intercellular bridges between primary oocytes in meiotic prophase I break down while single oocytes become closely surrounded by a squamous layer of pre-granulosa cells. Outside the pre-granulosa layer a basement membrane encompasses and demarcates each newly formed NGF.

Notably, assembly of a limited number of NGFs is accompanied by the degeneration of all the other oocytes in the clusters of cells surrounded by the squamous pre-granulosa cells and the basement membrane (Figure 1). More than $85 \%$ of germ cells degenerate, and it remains unclear whether there is specific selection for specific oocytes; whether the selection is random; whether those destroyed have any function in the process; or whether there may be insufficient auxiliary cells to support formation of more than a smaller number of follicles. Additionally, it is still unknown if the discarded oocytes provide any "nourishment" to surviving germ cells, as in Drosophila (reviewed in Pelosi et al., 2015). Nonetheless, several genes are known to be involved in the regulation of this process, and mutations in those genes have significant repercussions for the OR, as follows.

Figla is an oocyte-specific transcription factor required for primordial follicle formation (Soyal et al., 2000). When it is ablated in mice, oocytes fail to form follicles and eventually die soon after birth, leaving female but not male animals sterile. Figla is also important in maintaining femaleness and suppressing ectopic expression of male genes ( $\mathrm{Hu}$ et al., 2010). It has been shown to directly regulate the expression of $Z p 1, Z p 2$, and $Z p 3$, which encode the corresponding glycoproteins of the extracellular zona pellucida (Liang et al., 1997). Human FIGLA is also expressed in the oocytes of primordial follicles, suggesting a conserved function. Indeed, FIGLA mutation is a cause of POI in several Chinese POI patients (Zhao et al., 2008; "POF6" in OMIM 612310).

Also involved in primordial follicle formation, follistatin is involved in germ cyst breakdown and oocyte apoptosis. Mice expressing only a short isoform of follistatin displayed a larger OR, resulting from a reduction in germ cell apoptosis during germ cyst breakdown and a prolonged duration of the breakdown process itself (Kimura et al., 2011). However, these mice later lost the initial population of primordial follicles more rapidly than wildtype counterparts, so that other isoforms are likely required for the correct formation or maintenance of the OR.

The Notch signaling pathway is also implicated in the formation of the OR. Although mutations of various members of this family are embryonic lethal in mice (Conlon et al., 1995; 
Hrabĕ de Angelis et al., 1997; Jiang et al., 1998b; Xue et al., 1999; McCright et al., 2001), ovary cultures in which Notch signaling was disrupted by $\gamma$-secretase inhibitors contained fewer primordial follicles, with more of the oocytes persisting within the germ cysts (Trombly et al., 2009).

Neurotrophins, a family of growth factors involved in cell survival and development, are also activated in ovary development. Nerve growth factor $(N g f)$, its receptor (Ntrk1), and a related receptor (Ntrk2) have all been found to affect mouse primordial follicle formation. $\mathrm{Ngf^{-/ }}$ or $\mathrm{Ntrk} 1^{-/-}$ovaries showed a larger population of oocytes still inside germ cell cysts, and only a few primordial follicles were formed (Dissen et al., 2001; Kerr et al., 2009). In addition, neurotrophins Nt4 and Bdnf are likely involved in follicular assembly and/or survival, because germ cell death was increased in cultures when signaling was blocked (Spears et al., 2003). Still another neurotrophin, Nt3, and its receptor Ntrk3 also seem important for oocyte survival, and affect the transition of follicles from primordial to primary stage (Nilsson et al., 2009).

At the level of turnover of follicles, deletion of genes belonging to the apoptotic pathway also influenced the size and dynamics of the OR. Casp $2^{-/-}$mouse ovaries had more primordial follicles at $\mathrm{P} 4$, and germ cells were resistant to cell death following chemotherapy (Bergeron et al., 1998). Ovaries from mice in which the anti-apoptotic $B c l 2$ was ablated showed a reduced number of primordial follicles, with little or no significant effect on growing follicles (Ratts et al., 1995). Roughly one third of primordial follicles were aberrant, with a single layer of cuboidal granulosa cells but without any oocyte within. However, morphometric analysis was done on adult ovaries, and no data on the initial size or the OR was provided. Thus it is unclear whether $B c l 2$ is involved in germ cyst breakdown, oocyte survival during primordial follicle development, or both.

Deletion of the $\mathrm{Bcl} 2$-associated $\mathrm{X}$ protein (Bax), resulted in the formation of a larger mouse OR. Bax ${ }^{-/-}$ovaries contained larger numbers of PGC during embryonic development, and had more primordial follicles than wild-type ovaries at P4 (Greenfeld et al., 2007). Although this contradicted a previous study (Perez et al., 1999; see below), it was inferred that the phenotype of increased follicular endowment was due to BAX regulation of PGC survival or proliferation during migration to the developing gonad (Greenfeld et al., 2007).

It should be noted that deletion of $A h r$-a positive regulator of Bax (Matikainen et al., 2001) - produced mouse ovaries with no change during embryonic development (E18.5) but an increased population of primordial follicles at P2-P3 (Benedict et al., 2000). The number of primordial follicles returned to normal by P8 and remained very similar to wild-type until at least P32-P35. However, by P53 Ahr ${ }^{-/}$ovaries had fewer antral follicles, suggesting an action of AHR and BAX in follicle maturation as well as in primordial follicle endowment (Benedict et al., 2000).

Deletion of another apoptotic gene, $\mathrm{Mcll}$, caused a reduction in the OR that was significant as early as P7 and was almost total within 3 months. $\mathrm{Mcl1}^{-/-}$oocytes displayed elevated mitochondrial dysfunction with elevated superoxide levels, and also showed chromosome abnormalities, all of which could plausibly activate the autophagic pathway (Omari et al., 2015).
A very different class of factors affecting formation of the OR comprises retrotransposable elements and their expressed genes. Overexpression of L1 led to significant increase in oocyte loss during NGF endowment, thus affecting the size of the OR (Malki et al., 2014). Interestingly, oocyte survival was recovered by treatment with the reverse transcriptase inhibitor AZT, demonstrating the specific action of L1 retrotransposons (Malki et al., 2014). The involvement of retrotransposons in germ cells and follicle dynamics could be more prevalent than generally thought. In human oocytes, there is some evidence of retrotransposon expression (Georgiou et al., 2009), and more studies are warranted, especially given the potential relevance for development and disease.

\section{GENOMICS OF FOLLICULOGENESIS}

In the overall process, once they are formed, NGFs can remain quiescent in mice for up to $\sim 18$ months and in women for decades-or not even be used at all during reproductive life. They may undergo atresia before recruitment, or may instead be selected for maturation that will lead to the ovulation of one dominant oocyte competent for fertilization at each menstrual cycle. But the majority of assembled NGFs simply survive for long periods of time. If NGF dormancy is lost or they are damaged, follicular endowment is depleted by activation or death, respectively. This results in premature female reproductive aging and POI. One can therefore envisage two types of interventions that help to maintain the OR: (a) the maintenance of NGF quiescence and survival, and (b) the suppression of NGF activation (Adhikari and Liu, 2009; Reddy et al., 2010). Operationally the distinction is difficult, but stages in folliculogenesis can be discriminated, with many steps between the NGFs and the preovulatory or Graafian follicles, and those in turn can either ovulate their constituent eggs for fertilization or be lost by atresia.

Two events dominate folliculogenesis both in mouse and in human (Monniaux et al., 1997; McGee and Hsueh, 2000). In an initial step, NGFs are continuously recruited from OR (continuous recruitment) for their subsequent development until they have entered the antral cavity. In a successive step a few of the antral follicles are cyclically rescued to reach the preovulatory stage (cyclic recruitment).

In continuous recruitment the transition from primordial to primary follicles, termed follicle activation, results in morphological and physiological changes in both the germ and somatic cells. The volume of oocytes increases greatly, and the flattened pregranulosa cells surrounding the oocytes differentiate and proliferate into cuboidal granulosa cells. After activation follicles grow slowly (basal follicular growth), their growth rate tightly related to proliferation of granulosa cells. Most of the activated follicles undergo atresia.

In cyclic recruitment, in contrast, follicular growth is rapid and occurs by enlargement of the antrum (terminal follicular growth). In women, as in all mono-ovulatory species, only one of these follicles, the "dominant follicle," is usually selected for ovulation of a fully competent oocyte every cycle, while the subordinate selected antral follicles are discarded by atresia. 
Continuous recruitment with basal follicular growth is mainly under the control of growth factors of paracrine origin, and is gonadotropin-independent-though follicle-stimulating hormone (FSH) may exert an indirect mitogenic effect on granulosa cells by enhancing expression of growth factors or growth factor receptors. In contrast, cyclic recruitment with terminal follicular growth is strictly gonadotropin-dependent. FSH plays determinant roles in enhancing granulosa cell differentiation and survival. These actions are again mediated or modulated in an important way by paracrine factors, particularly steroids and growth factors. Luteinizing hormone (LH) stimulates steroidogenesis in theca cells and sustains terminal maturation of granulosa cells in pre-ovulatory follicles.

In the human ovary continuous recruitment begins early in prenatal life. Instead, cyclic recruitment occurs only after puberty. Primary follicles have been observed in 17-week old XX fetuses (Kurilo, 1981). By 23-26 wpc pre-antral follicles are also present, and after 35 weeks all follicle stages, primary to antral, can be observed (van Wagenen and Simpson, 1965; Sforza et al., 1993).

\section{Genes Involved in the Gonadotropin-Independent Phase}

Based on both human studies and mouse models, factors involved in the transition from primordial to primary follicles include SOHLH1/2, NOBOX, LHX8, KIT, YBX2, and FOXO3-all expressed in the oocytes-and KITL and FOXL2, expressed in the granulosa cells. Signaling from other cell lineages may also influence NGF quiescence or recruitment, but specific actions are less studied.

One of the most powerful factors is Foxl2, which acts critically in several processes, including sex determination, ovary development and maintenance of gonadal femaleness. In humans, mutation of FOXL2 causes Blepharophimosis/Ptosis/Epicanthus Inversus syndrome (BPES), characterized by eyelid anomalies and POI (Crisponi et al., 2001). Foxl2 is never expressed in the testis, and is turned on specifically in granulosa cells of the ovary at the time of sex determination. When Foxl2 is ablated in female mice, granulosa cells in the ovary undergo partial sex reversal, characterized by expression of male specific markers including testis-determining Sox9. Joint ablation of Wnt4 and Foxl2 drives sex determination more decisively toward the testis fate during embryonic life, causing sex reversal that now extends to germ cells (Ottolenghi et al., 2007). Foxl2 also acts negatively on expression of Cyp26b1 and Sf1, which are required for male sex determination (Kashimada et al., 2011a; Takasawa et al., 2014). Furthermore, FOXL2 cooperates with BMP2 in regulating the correct expression of follistatin, which in itself is also required for female sex determination and ovary development (Kashimada et al., 2011b). Foxl2 ablation causes primordial follicle failure in progression to the primary stage, resulting in female sterility, while the steroidogenic profile resembles that of testis, with the up-regulation of Amh and Cyp11a1 and the inhibition of Cyp19a1 (Uda et al., 2004; Ottolenghi et al., 2007). Foxl2 expression remains obligatory throughout the entire reproductive lifespan (GarciaOrtiz et al., 2009). Indeed, when Foxl2 is ablated in the adult ovary the somatic compartment comprising granulosa and theca cells transdifferentiate to Sertoli-like and Leydig-like cells (Uhlenhaut et al., 2009).

Sohlh1 and Sohlh 2 share a similar function in germ cells, and their ablation in mice results in the impairment of the transition from primordial to primary follicles, with subsequent premature follicle loss (Pangas et al., 2006; Choi et al., 2008a). Sohlh1 has been shown to directly regulate $\operatorname{Lhx} 8$ (Pangas et al., 2006), a transcription factor involved in oocyte survival; its deletion in mice also causes rapid oocyte loss (Choi et al., 2008b). When Lhx8 is ablated, primordial follicles fail to progress to the primary stage and soon degenerate, leaving the ovary empty by P7 (Choi et al., 2008b). Lhx8 directly affects expression of the homeobox gene Nobox (Park et al., 2012), another transcription factor that seems required for the transition to primary follicles. Nobox ${ }^{-/-}$mouse ovaries appear very similar to their wild-type counterparts. However, the oocytes are developmentally impaired, with many germ cell cysts still present at P3 in Nobox ${ }^{-/-}$ovaries; progression beyond the primordial stage is blocked, and follicles are nearly completely lost by P14 (Rajkovic et al., 2004).

Because these genes-Sohlh1 and Sohlh2, Lhx8, and Nobox-belong to the same regulatory pathway, the similarities in phenotype when they are ablated are not surprising. Several of them have also been associated with POI in women. LHX8 was not found changed in any of a cohort of Caucasian patients (Qin et al., 2008); and SOHLH1 mutations or variants have not been evaluated, so that there may be a failure of ascertainment in that case. By contrast, eleven variants in the oocyte gene SOHLH2, including four mutations detrimental to its function, have been found associated with POI (Qin et al., 2014). As for NOBOX ("POF5" in OMIM 611548), it was first shown to be mutated in 1 of 96 POI cases analyzed (Qin et al., 2007). Strikingly, sequencing of $N O B O X$ in a cohort of 178 women with POI found mutations in 12 (6.2\%), and lesions in NOBOX may thus be a substantive cause of POI at a population level. All the characterized mutations compromised binding to the GDF9 promoter (Bouilly et al., 2011), which would indeed arrest development. Other studies have reported deletions of NOBOX associated with POI (Rossi et al., 2008; Sehested et al., 2010).

Ybx2, also known as $M s y 2$, is a germ cell-specific factor encoding a DNA/RNA binding protein. When mutated, it causes infertility in both male and female mice, likely due to instability of cytoplasmic transcripts (Yu et al., 2001). Ablation of Ybx2 in the ovary results in follicle loss starting at around 3 weeks, accompanied by anovulation and absence of cumulus cells (Yang et al., 2005).

Foxo3 is a potent transcription factor involved in follicle activation. In the mouse ovary, Foxo3 is expressed exclusively in the oocytes of primordial and early growing follicles. FOXO3 is regulated by phosphorylation of $\mathrm{AKT}$, which induces its translocation to the cytoplasm and therefore effectively blocks its nuclear function (John et al., 2008). When Foxo3 is ablated in mice, all the primordial follicles start growing uncontrollably and the ovary becomes void of follicles by 15 weeks (Castrillon et al., 2003). It has been shown that Galt1 is a downstream target of Foxo3. Prolactin signaling through the short form of its receptor causes Foxo3 down-regulation, and consequently Galt1 repression, again leading to accelerated follicle recruitment and 
POI (Halperin et al., 2008). This is of particular interest because human GALT deficiency causes galactosemia, another cause of POI (Pelosi et al., 2015; OMIM 230400).

Because of its function in controlling the OR dynamics, lesions in the human FOXO3 seem a plausible candidate to cause POI. However, studies in women have been inconclusive (Gallardo et al., 2008), consistent with the finding that FOXO3 does not seem to be expressed in human oocytes (Tarnawa et al., 2013). In fact, FOXO3 has been found reported to be expressed in granulosa cells rather than oocytes in human ovaries, where instead FOXO1 may take over its function (Tarnawa et al., 2013). Conversely, Foxo1 is expressed in mouse somatic cells but not oocytes, suggesting a differentially evolved mode of regulation between human and mouse ovaries. No involvement of Foxo1 in POI has been reported, but this may rather reflect the widespread requirement for FOXO1 action in many tissues.

One might anticipate that other factors belonging to the PI3K/AKT pathway might participate in controlling size of the OR. Indeed, one of these factors, Pten, encodes a lipid phosphatase that negatively regulates $\mathrm{PI} 3 \mathrm{~K}$, and is also involved in setting the rate of follicle activation in mice: oocyte-specific deletion of Pten again leads to massive primordial follicle recruitment (Reddy et al., 2008). However, as with FOXO genes, changes in PTEN have at least as yet not been found in human POI (Shimizu et al., 2009; Zhao et al., 2011).

Quiescence of primordial follicles is further regulated by a complex of TSC1 and TSC2, which act by inhibiting the activity of mTOR complex1. Deletion of Tsc2 in mouse oocytes caused increased mTOR activity followed by accelerated recruitment of the OR starting by P23 and follicle depletion by 4 months (Adhikari et al., 2009). A similar POI-like phenotype was also observed in mice with oocyte-specific deletion of Tsc1 (Adhikari et al., 2010). Interestingly, double knock-out of Tsc1 and Pten enhanced the effect on follicle recruitment compared to single gene mutants (Adhikari et al., 2010). These results suggest an additive effect between Tsc1 and Pten, consistent with overlapping functions of the mTOR and AKT pathways in regulating the dynamics of the OR. Notably, another factor involved in both mTOR and AKT signaling is PDK1, and oocyte-specific deletion of Pdk1 again caused accelerated mouse follicle loss, consistent with a role for this gene as well in follicle survival (Reddy et al., 2009). Moreover, the authors suggested a model in which PDK1 activity lies at the decision point between loss and activation of the OR.

P27KIP1 also participates in maintaining NGFs in a quiescent state. In $p 27 k i p 1^{-/-}$mice, primordial follicles were prematurely recruited and subsequently lost, causing POI comparable to that seen in Foxo3 ${ }^{-/-}$ovaries (Rajareddy et al., 2007). However, it was shown that P27KIP1 and FOXO3 acted independently. In addition, unlike Foxo3, p27kip1 is expressed in both oocytes and granulosa cells of primordial and growing follicles, thereby affecting proliferation and survival of granulosa cells as well (Rajareddy et al., 2007).

Hippo signaling provides still another pathway inhibiting follicle recruitment (Kawamura et al., 2013). This pathway is characterized by the action of MST1 and MST2-orthologous to Hpo (Hippo) in Drosophila-which along with SAV1, phosphorylate LATS1/2. That leads to further phosphorylation and later degradation of YAP and TAZ, and results in suppression-or at least limitation-of follicle recruitment. When Hippo signaling is disrupted in mice, YAP and TAZ are active and interact with TEAD transcription factors, activating transcription of downstream target genes including Ctgf and Naip (Kawamura et al., 2013). CTGF is involved in follicle development, and $C t g f^{-/-}$mice were subfertile, had decreased ovulation rates, and increased apoptosis of granulosa cells (Nagashima et al., 2011). Furthermore, statistically significant copy number variations of NAIP, which is involved in inhibition of apoptosis, were found in POI patients of Caucasian origin (Aboura et al., 2009).

Two genes acting upstream in the Hippo pathway, DIAPH2 and DIAPH3, were also found associated with menopause. Castrillon and Wasserman (1994) had identified the dia locus in Drosophila by screening for male sterility mutations, and found alterations in cytokinesis associated with mutated dia alleles. In women, the Xlinked gene DIAPH2 was disrupted by a breakpoint in a family with POI ("POF2A," OMIM 300511; Bione et al., 1998), and more recently variants in the gene were also found associated with the regulation of the age of menopause (He et al., 2010). Variants of DIAPH3 have now been reported associated with both timing of menopause and size of the OR (Schuh-Huerta et al., 2012).

Amh-another member of the TGF $\beta$ superfamily-starts to be produced in granulosa cells of mouse follicles starting at the primary stage (Durlinger et al., 2002a). In $A m h^{-/-}$ovaries, the number of growing follicles was larger than control, whereas depletion of primordial follicles became significant by 4 months of age (Durlinger et al., 1999). When neonatal ovaries were cultured in vitro in presence of $\mathrm{AMH}$, growing follicles were reduced by $40-50 \%$ after 2 and 4 days (Durlinger et al., 2002b). In addition, when preantral follicles were cultured in presence of $\mathrm{AMH}, \mathrm{FSH}$-induced follicle growth was inhibited. A similar result was obtained when $A m h^{-/-}$mice were treated with FSH: follicle recruitment was greater than in wild-type females (Durlinger et al., 2001). These results confirm a dual role for AMH: during gonadotropin-independent recruitment it inhibits the transition from the primordial to the primary stage, whereas in the gonadotropin-dependent phase it antagonizes responsiveness to FSH.

Follicle recruitment as well as folliculogenesis are dominated by communication between oocyte and granulosa cells.

Two important oocyte factors involved in follicle growth are Gdf9 and Bmp15, both members of the transforming growth factor beta superfamily. They are 52\% homologous and have similar functions, primarily involved in the progression of follicle maturation (Yan et al., 2001).

Gdf9 is necessary for fertility, because its ablation in mice causes a block in follicle growth at the primary stage (Yan et al., 2001). Additionally, Gdf9 actively induces granulosa cell proliferation; formation of the theca layers and promotion of androgen biosynthesis from theca cells (Solovyeva et al., 2000); and expansion of the cumulus cells. Hence it is actively involved in the communication between the oocyte and surrounding somatic cells (Dong et al., 1996; Elvin et al., 1999).

By contrast, Bmp15 ablation in mouse does not result in infertility. However, mice are subfertile, have a reduced litter size, 
and display impairment of ovulation and fertilization, suggesting a prevalent role of Bmp15 in the peri-ovulatory period (Yan et al., 2001).

Interestingly, Gdf9 and Bmp15 both appear to be involved in the breakdown of ovigerous cords as well, because mouse mutant ovaries showed significant numbers of follicles containing multiple oocytes (Yan et al., 2001).

Mutations in GDF9 have also been associated with POI in several populations, including missense mutations in a cohort of Indian patients (Dixit et al., 2005) as well as POI cases of Caucasian, Chinese, and African origin (Laissue et al., 2006; Kovanci et al., 2007; Zhao et al., 2007). BMP15, an X-linked gene, has also been associated with a substantial number of instances of POI ("POF4" in OMIM 300510). Rossetti et al. (2009) screened 300 unrelated idiopathic overtly POI women and identified six non-synonymous BMP15 variants in 29 of them. Other reports have noted additional associated mutations in BMP15 (Di Pasquale et al., 2004; Dixit et al., 2006; Laissue et al., 2006).

A member of the connexin family, connexin 43 , is directly involved in cell-cell communication and is necessary for the correct development of growing follicles. Although ovaries from $C \times 43^{-/-}$mice seemed grossly similar to wild-type up to several weeks after birth, growing follicles failed to complete maturation to the Graafian stage. In addition, mutant ovaries showed premature luteinization, and oocytes were likely impaired in completing meiosis to achieve competence.

Related to the interplay between oocyte and somatic cells, growth factor Rspo2 is also involved in folliculogenesis, and particularly in inducing the development from primary follicles to more advanced developmental stages (Cheng et al., 2013). RSPO2 is produced by the oocyte from the primary stage onward, and functions both in vitro and in vivo as a paracrine factor able to stimulate follicle maturation. Additionally, when human cortical cubes where transplanted into the kidney capsule of immunedeficient mice, RSPO2 treatment was effective in promoting the transition of human primary to secondary follicles (Cheng et al., 2013). Interestingly, a mouse model hypomorphic for Rspo 2 showed that in addition to skeletal malformations, females had a reduced reproductive lifespan resembling POI (Bell et al., 2003). However, RSPO2 function in humans still remains to be assessed, and thus any association with POI is not known.

\section{Genes Involved in the Gonadotropin-Dependent Maturation Phase}

Maturation occurs with the integration of extra-ovarian signals and intra-follicular factors to determine whether an antral follicle will continue to develop or be diverted into atretic pathways. Cyclic follicular recruitment is characterized by induction of expression of mRNAs encoding a range of steroidogenic enzymes, gonadotropin receptors, and local regulatory factors. FSH provides the primary extra-ovarian driver for cyclic follicular recruitment, and LH (lutropin) is required for further development of follicles to the pre-ovulatory stage. FSH acts through membrane-associated granulosa cell receptors (FSHR) to stimulate granulosa cell proliferation and differentiation. The most responsive follicle at the beginning of the cycle is the first to produce estrogen and express $\mathrm{LH}$ receptor (LHR) on granulosa cells.

Follicle-stimulating hormone production is itself regulated by inhibin $\alpha$ (Inha), a glycoprotein member of the TGF $\beta$ superfamily (Vale et al., 1986). Inhibins are considered among the biomarkers of OR in predicting human reproductive lifespan (Steiner, 2013). Inha ${ }^{-/-}$mice are infertile due to compromised follicular development and the formation of mixed tumors of granulosa and theca or undifferentiated stromal cells (Matzuk et al., 1992). After screening patients with POI or primary or secondary amenorrhea, Dixit et al. (2004) found a missense mutation in INHA associated with POI, though no associated variants were found in INHBA or INHBB. Confirming the positive finding, other reports have also found mutations and variation of INHA involved in POI in several populations (Shelling et al., 2000; Marozzi et al., 2002; Harris et al., 2005; Woad et al., 2009).

Disruption of the inhibin-activin-follistatin pathway also occurs in Taf $4 b^{-/-}$female mice (Freiman et al., 2001). TAF4B is a subunit of transcription factor TFIID, which participates with RNA polymerase II, and was found specifically expressed in ovarian granulosa cells. Taf $4 b^{-/-}$mice were sterile, and mutant ovaries showed a sharp decrease in numbers of growing follicles and failure of oocyte maturation and/or fertilization. No follow-up has reported whether TAF4B affects the transcription of a targeted subset of genes.

Follicle-stimulating hormone is also a predictor of reproductive lifespan, controlling development of follicles to the antral stage, as shown by targeted mutation of Fshb in mice (Kumar et al., 1997). Furthermore, the same phenotype was observed by disruption of the FSH receptor, confirming the importance of this signaling pathway for the completion of folliculogenesis (Dierich et al., 1998). Missense mutation in FSHR associated with POI has been reported in Finnish patients (Aittomaki et al., 1995; Jiang et al., 1998a; Doherty et al., 2002). However, some FSHR variants have been found in both POI cases and controls (Sundblad et al., 2004), and mutations causative of POI are rare (Layman et al., 1993; da Fonte Kohek et al., 1998). Variants in FSHB were nevertheless found associated with age of menopause in Caucasian women ( $\mathrm{He}$ et al., 2010), and one of those single nucleotide polymorphisms was reported associated with age of menopause in women of African origin as well (Spencer et al., 2013).

FSH increases the expression in mouse granulosa cells of Ctype natriuretic peptide (CNP) - encoded by the Nppc gene-but not its receptor NPRB (Sato et al., 2012). Unlike FSH signaling, which is mediated mainly through cAMP, CNP uses cGMP specifically as second messenger (Sato et al., 2012). In Nppc and Nprb hypomorphic mice, meiotic arrest was reversed prematurely, and although ovulation occurred seemingly normally, female mice were unable to deliver offspring. These results suggested the importance of CNP/NPRB signaling for correct and synchronized maturation of oocytes and cumulus cell differentiation from granulosa cells (Zhang et al., 2010; Kiyosu et al., 2012). In addition to skeletal defects and survival problems, $N p r b^{-/-}$mice also showed arrest of ovarian follicles at the pre-antral stage (Tamura et al., 2004). 
The LH signaling pathway is responsible for inducing ovulation and luteinization through the coordinated cooperation of theca and granulosa cells. LH stimulates theca cells to produce androgens, which are then converted into estradiol by the granulosa cells (Pelosi et al., 2015). Consequently $\mathrm{Lh}^{-/-}$mice are infertile, and mutant females show degenerating antral follicles and an absence of corpora lutea (Ma et al., 2004). In addition, levels of estrogen and progesterone were lower than in wild-type mice. Confirming the hormonal basis of the phenotypes, $L h^{-/-}$ mice can be rescued by chorionic gonadotropin administration. $\mathrm{Lhr}^{-/-}$mice are comparably infertile, and ovaries contained follicles only up to the early antral stage, with no corpora lutea and elevated LH (Zhang et al., 2001). In humans, a variant has been found associated with the timing of menopause (He et al., 2010).

In granulosa cells, the surge of LH ultimately leads to the activation of downstream factors including RAS, ERK1/2, and EGFR. When a constitutively active form of Kras was expressed in granulosa cells, transgenic mice showed impairment of ovulation, decreased ERK1/2 activity, and elevation of Protein kinase B, PKB (AKT) function. The result in the mice was subfertility and POI (Fan et al., 2008). Disruption of Erk1/2 in granulosa cells itself caused female infertility due to ovulation failure; and it was further shown that Erk 1 and Erk2 are required for the LH-induced resumption of meiosis in oocytes and the attendant ovulation and luteinization (Fan et al., 2009).

$\mathrm{C} / \mathrm{EBP} \beta$, a downstream mediator of $\operatorname{Erk1/2}$, is also important in the response to the LH surge. Indeed, deletion of Cebpb in mouse granulosa cells caused subfertility, whereas Cebpa/b double knock-outs were sterile. Cebpa/ $b^{-/-}$ovaries failed to ovulate and were devoid of corpora lutea, indicating the importance of Cebpa and Cebpb in regulating the terminal differentiation of granulosa cells during the luteinization process (Fan et al., 2011). Targeted disruption of Egfr in granulosa cells caused impaired oocyte meiotic resumption and impaired cumulus expansion, with reduced ovulation and fertility (Hsieh et al., 2011); the LHinduced activation of ERK1/2, p38MAPK, and connexin-43 was also impaired.

Estrogen signaling is also critical for folliculogenesis and reproduction. Disruption of the estrogen receptor gene in mice caused infertility; arrest of folliculogenesis with absence of corpora lutea; and absence of mating behavior that was not restored even with estrogen supplementation (Lubahn et al., 1993). Additionally, deletion of Esr1? in theca cells resulted in premature loss of mouse fertility similar to POI (Lee et al., 2009). In fact, polymorphisms of ESR1 in women have been found associated with POI and idiopathic infertility (Bretherick et al., 2008; Yoon et al., 2010; Du et al., 2011; Cordts et al., 2012; M’Rabet et al., 2012).

\section{Other Genes Involved in Folliculogenesis}

Variants in still other genes have been found causative of POI, but their involvement in ovarian development has not yet been studied extensively. Duncan et al. (2012) reviewed 13 cases of mutations in $P O L G$, the mitochondrial DNA polymerase, that were associated with POI-and frequently also with neurological symptoms and male infertility. Current data indicate that $P O L G$ variants can also affect the timing of normal menopause (Stolk et al., 2012;
Shen et al., 2013). One study found no association (Bonomi et al., 2012), but examined only a small number of cases. As another example, Clast4 is highly expressed in mouse oocytes during follicle maturation, but its function is still poorly understood (Villaescusa et al., 2006). However, dominantly inherited mutation of its human ortholog-protein initiation factor 4E nuclear import factor 1 (EIF4ENIF1) - was inferred as causative of POI in a 3-generation family (Kasippilai et al., 2013).

Although endocrine disorders, including hypothyroidism, adrenal insufficiency, and hypoparathyroidism, all affect the hormonal profile required for fertility, only a few POI cases have been associated with mutations in genes of the endocrine system. Most suggestively, NR5A1 (Steroidogenic factor Sf1), a gene involved in gonadal differentiation and steroidogenesis (Tremblay and Viger, 2003; Takasawa et al., 2014), is mutated in "POF7" in OMIM 612964. Lourenco et al. (2009) identified missense, frameshift, and in-frame mutations in NR5A1 in families with anomalies of ovarian development and function, and in 2 of 25 sporadic cases of POI.

As for other endocrinological genes, Bhangoo et al. (2007) reviewed cases of females with deficiency in the steroidogenic acute regulatory $(S T A R)$ protein who showed recessive steroidal hormone and adrenal insufficiency leading to POI. Zangen et al. (2011) attributed POI in a case of Arab Palestinian origin to mutation in PSMC3IP, abolishing co-activation of estrogendriven transcription. In another study, no mutations of PSMC3IP were found in Swedish POI patients (Norling et al., 2014), but ascertainment in such studies is often limited by small numbers of patients and the large number of known "POI" genes.

\section{NON-CODING RNAS}

As in other physiological systems, it is increasingly evident that small non-coding RNAs are essential in the regulation of ovarian physiology. The classes expressed in the ovary include piwi interacting RNAs (piRNAs); small interfering RNAs (siRNAs); microRNAs (miRNAs); and long non-coding RNAs. We cannot comment on analyses of lncRNAs in the dynamics of the OR, because systematic studies have not yet been reported. It is currently believed that piRNAs are required primarily for mammalian male spermatogenesis rather than oocyte or ovary development. Several mouse models showed important roles of piRNAs in the male germline (Deng and Lin, 2002; KuramochiMiyagawa et al., 2004; Aravin et al., 2007; Carmell et al., 2007). Instead, despite known functions in oogenesis in lower organisms (Thomson and Lin, 2009), a study in female mice showed that deletion of a piRNA interacting protein had no effect on female germline development (Kuramochi-Miyagawa et al., 2004). Consistent with these findings, Dicer 1 (see below) affects ovarian function, but is required for siRNAs and miRNAs, and not for piRNA formation. Thus, the presence of piRNAs in the ovary may be adventitious.

A variety of other mouse models have explored the involvement of miRNAs in diverse cells and processes in the ovary.

Conditional deletion of Dicer1 in oocytes resulted in sterility (Murchison et al., 2007). Although ovaries were grossly normal and responsive to gonadotropins, oocytes were arrested in meiosis 
I and showed spindle and chromosome congression defects. Mutant oocytes had increased numbers of maternal transcripts and up-regulation of genes involved in microtubule organization, suggesting that regulated degradation of these classes of mRNAs promoted by siRNAs, and miRNAs may be critical (Murchison et al., 2007).

Conditional deletion of Dicer1 in granulosa cells also resulted in sterility (Nagaraja et al., 2008). In addition to defects in the uterus and oviduct, granulosa cells in the ovary showed increased apoptosis, and fewer oocytes ovulated following superovulation, with some oocytes remaining trapped inside luteinized follicles (Nagaraja et al., 2008). Examination of a different group of ovaries in which Dicer 1 was ablated only in granulosa cells revealed that primordial follicle endowment was increased in Dicer $1^{-/-}$, leading to accelerated follicle recruitment that was, however, negated by an increase in follicle degeneration (Lei et al., 2010).

The generation of a mouse model with a hypomorphic Dicer1 allele provided further information about the role of small RNAs in the ovary. Mutant males were fertile, whereas females were sterile, and this was specifically due to DICER1 deficiency, because mutant females that received ovary transplantation from a wild-type mouse were able to deliver normal offspring (Otsuka et al., 2008). The mutant females showed luteal insufficiency due to impaired angiogenesis of the corpora lutea. The authors attributed this phenotype to the lack of two miRNAs, miR17-5p and let7b, that regulate antiangiogenic factor Timp1. However, injection of these miRNAs failed to completely rescue pregnancy in mutant females, so that other small RNAs may be involved.

The lin28/let7 system specifically affects for mouse germ cell development and OR formation. Male and female mice ablated of lin28, a RNA-binding protein that represses let7, showed early defects in PGC proliferation. Whereas in males this was partially corrected in adult life due to the continuous proliferation of spermatogonial stem cells, females-whose germ cells do not proliferate in the adult-formed a smaller OR and had reduced fertility (Shinoda et al., 2013). This phenotype was replicated by overexpression of let7, confirming the specific action of the lin28/let7 system in regulating the size for the OR (Shinoda et al., 2013).

As a clue to timing, hormones were found to regulate miRNA expression in the granulosa cells of the mouse ovary. After in vitro FSH treatment 31 miRNA species were differentially expressed in granulosa cells. Interestingly, the expression of miR-29a and miR30d decreased significantly $12 \mathrm{~h}$ after FSH supplementation, and then increased again by $48 \mathrm{~h}$, suggestive of a complex feedback circuit (Yao et al., 2010b). Following treatment with LH/hCG, Fiedler et al. (2008) found that 13 miRNA's were differentially expressed in peri-ovulatory granulosa cells, and in particular miR132 and miR-212 showed higher expression. The authors found 77 putative mRNA targets of miR132 and miR-212, with CTBP1, a known miR-132 target, among them.

More recently, in vitro experiments on primary human granulosa cells that were transfected with anti-miR-15a, or alternatively with pre-miR15a, showed that this miRNA affects a series of processes including proliferation, apoptosis, and hormone synthesis (Sirotkin et al., 2014). The same investigators had previously identified a group of microRNAs involved in the repression of estrogens, androgens, and progesterone (Sirotkin et al., 2010). MiR-21 is also involved in the apoptosis of granulosa cells during luteinization, but no target of its action has thus far been identified (Carletti et al., 2010).

In vitro experiments in which miR-378 was over-expressed or inhibited in porcine granulosa cells revealed a role in regulating aromatase-and thus estradiol-levels. In addition, two miR-378 binding sites that were critical for its function were identified in the aromatase coding region (Xu et al., 2011). It was also shown that miR-133b binds to Foxl2 mRNA, thus inhibiting its expression and its ability to induce expression of StAR and aromatase (Dai et al., 2013). Another miRNA, miR-224 was shown to be induced by TGF $\beta$, and subsequently increases estradiol production by granulosa cells in vitro through elevation of aromatase mRNA levels (Yao et al., 2010a).

Experiments in the bovine ovary provided further information about important miRNA action in the ovary and early embryo development. miR-196a is a regulator of NOBOX expression in the bovine ovary. A putative miRNA recognition element was identified in the $3^{\prime}$ UTR of NOBOX mRNA, and its binding activity was confirmed by luciferase assays. Injection of miR-196a in bovine embryos significantly decreased NOBOX expression at both the mRNA and protein level (Tripurani et al., 2011). Because NOBOX variants are associated with human POI, it would be particularly interesting to assess the function of miR-196a in POI patients.

In addition, bovine miR-181a was found to be involved in the regulation of oocyte-specific NMP2, a protein critical for DNA remodeling. MiR-181a is a maternally inherited miRNA that binds to the $3^{\prime}$ UTR of the NMP2 transcript and is involved in early embryo development (Lingenfelter et al., 2011). Ma et al. (2011) found a second role for miR-378, involvement in apoptosis during luteinization, and identified IFNGR1 as a putative miR-378 target. It remains to be seen if these functions are conserved in other species.

The majority of experiments thus far have been conducted in vitro on isolated cells, and most importantly, the function of these miRNAs has not been evaluated with regard to the OR. Nevertheless, these results demonstrate the relevance of small regulatory RNAs in important processes of ovarian function. Thus, their validation with in vivo models could provide exciting results, identifying additional points of control in the regulation of fertility and reproductive lifespan. One potential role of miRNA's in OR dynamics might well be in the initial recruitment of primordial follicles. Consistent with such a role, when mouse P3 and P5 ovaries were compared, 24 miRNA's were found differentially expressed. The authors showed that inhibition of miR-145 induced primordial follicle recruitment, and suggested that miR-145 as particularly associated with regulation of the TGF $\beta$ pathway in granulosa cells of primary follicles (Yang et al., 2013). Microarray analysis of RNA profiles in a rat model of POI identified 63 miRNA's that were differentially expressed in POI vs control ovaries. Once again, apoptosis was one of the main putative pathways regulated by some of these miRNA's, along with other pathways including hormone response and prostaglandin biosynthesis (Kuang et al., 2014). 
Recently, some miRNAs have also been reported to be correlated with POI in human. Zhou et al. (2011) measured miRNA expression in the serum of Chinese normal and POI patients, and found 12 miRNA's that were differentially expressed (Zhou et al., 2011). Another study with a similar approach found differentially expressed miRNA's in plasma of POI patients, suggesting that several pathways, including AKT signaling and steroid hormone receptor pathways, might be regulated by these miRNA's. Additionally, the authors provided evidence for miR23a function in granulosa cell apoptosis and suggested a role in POI (Yang et al., 2012). Rah et al. (2013) investigated the association of miRNA variants in Korean POI patients and described risk and protective effects of combinations of three miRNA polymorphisms. However, none of the polymorphisms was independently associated with POI (Rah et al., 2013). Finally, a microarray analysis of POI patients identified a panel of 51 differentially expressed miRNA, several of which were further validated. In particular, miR-22-3p, involved in apoptosis and tumorigenesis, was suggested to be protective against POI and negatively correlated with serum FSH (Dang et al., 2015).

One caveat for many of the miRNA determinations during ovary aging is that they do not take into account the changing composition of the ovary as the OR declines in normal aging or in POI. This makes further work necessary to determine which variations in miRNA may be truly associated with POI from those that merely reflect the loss of follicles.

\section{INTERVENTIONS AFFECTING THE TIME OF MENOPAUSE IN MOUSE MODELS}

Because women in modern societies are reproducing later (Martin et al., 2011), investigations of possible interventions to prolong reproductive lifespan are increasing. Understandably, such studies have been performed in animal models to try to understand the mechanisms involved. However, a complication is that in some mammals the ovary seems to be able to "sense" the size of the follicle reserve and to compensate for both innate and induced changes. The precise molecular pathways involved in this "sensing" mechanism, and why such a mechanism exists, are unknown. It may be necessary for the selection of the best quality oocytes or to limit premature decline in numbers of primordial follicles - that is, precisely in the mechanism whereby the time of menopause is so narrowly restricted.

During embryonic development, for example, XO female mice initially generate more germ cells than XX mice (Burgoyne and Baker, 1985). However, the atresia following the peak production of germ cells is much more extensive in the $\mathrm{XO}$ mice, leaving the perinatal XO ovary with half the number of primordial follicles of the XX ovary. Consequently, due to the reduced OR, XO female mice become sterile earlier than XX mice. However, the rate of depletion of the OR was found to be the same in XO vs XX mice (Burgoyne and Baker, 1981). In other words, the same constant proportion of primordial follicles is lost over time, allowing for a delimited period of fertility in $\mathrm{XO}$ animals.

Interventions aiming rather to increase the OR have been successful, but only temporarily. Animals transgenic for the antiapoptotic $B c l 2$ were born with a significantly larger population of follicles (Flaws et al., 2001). This was likely due to BCL2 protection against apoptosis during embryonic and perinatal development. However, a compensatory mechanism was again soon evident in this case, with the OR returning to wild-type levels by 30-60 days after birth (Flaws et al., 2001). Similar results were obtained when pups were administered activin A, a factor involved in germ cell proliferation before primordial follicle formation (Bristol-Gould et al., 2006). The larger numbers of follicles generated in treated mice did not persist until puberty but were rather lost, again consistent with the existence of a "census mechanism" that could aid in germ cell quality control.

The size of the primordial follicle pool of Casp $2^{-/-}$mice was also larger than wild-type in $\mathrm{P} 4$ ovaries, and oocytes were resistant to doxorubicin-induced apoptosis (Bergeron et al., 1998). However, the dynamics of the OR was not evaluated, and it was not shown if this phenotype persisted in older ovaries.

Another gene involved in cell death, Smpd1, encodes sphingomyelinase phosphodiesterase 1 , an important factor in generating the signal for apoptosis. $\operatorname{Smpd1} 1^{-/-}$ovaries showed a down-regulation of apoptosis at E13.5 in vitro, and Smpd1 $1^{-/-}$ mice had an increased population of primordial, primary, and pre-antral follicles both at P4 and P42. These findings suggested a critical role for SMPD1 in controlling the size of the OR. However, follicle numbers in older ovaries were not assessed (Morita et al., 2000).

More lasting effects were demonstrated by ablation of proapoptotic Bax in mice (Perez et al., 1999). Although the number of follicles was the same in $B a x^{-/-}$and WT mice at birth, significant follicle numbers and maturation were still seen up to 640 days post birth. However, aged $\mathrm{Bax}^{-/-}$female mice failed to become pregnant by natural reproduction, suggesting that quality or performance was defective.

Another model manipulated Foxo3. Generation of transgenic mice harboring a constitutively active form of Foxo3 (engineered so that it could not be inactivated by phosphorylation) successfully increased the ovarian follicle reserve throughout mouse reproductive life (Pelosi et al., 2013). In addition, age-related increase of gonadotropin levels was diminished in transgenic animals and fertility was increased by up to $49 \%$. Interestingly, increased fertility remained significant throughout the entire period of observation (Pelosi et al., 2013).

Ablation of interleukin 1 (Il1) also resulted in prolongation of fertility in mice. There was no difference in follicle numbers between $I l 1^{-/-}$and wild-type ovaries throughout reproductive lifespan (apart from a transient increase in secondary and antral follicles at 2.5 months that was later compensated). However, the increase in fertility observed at 2.5 months of age persisted until 12 months. This suggested that the observed decreased expression of pro-inflammatory cytokines in $\mathrm{Il}^{-/}$ovaries might affect follicle dynamics (Uri-Belapolsky et al., 2014).

Finally, inactivation of the mTOR pathway by rapamycin also preserved primordial follicles in young 20 week old rats (Zhang et al., 2013), and caloric restriction gave similar results (Li et al., 2015). Especially if these effects prove to be long-lasting, these approaches would provide epidemiological interventions that are potentially at hand. 


\section{CONCLUSION}

Appropriate to the critical process by which reproduction and continuity of a species are maintained, formation and stabilization of follicles is intricate. The ovary, like all organs, contains cells of numerous lineages that must organize and cooperate in coordinated regulation to produce competent and optimal quality germ cells for fertilization and development of embryos. A wide variety of pathways are coordinated, and the $\mathrm{OR}$ is thus sensitive to many insults, that are often dosage-dependent. Thus, in general, genes that cause POI in humans have loss-of-function in only one allele; the resultant heterozygous women have the pathognomonic reduction in OR; and as might be expected, the knockout phenotypes in corresponding mouse models are far more severe, frequently showing complete loss of OR.

Although many genes involved in ovary development and function have been characterized, many more are vital participants in the implicated pathways, and many other genes and pathways that affect individual lineages and their interactions are certainly still unidentified.

Among the important open questions is the extent to which epigenetic changes through life may affect folliculogenesis and the OR. Thus far, a few studies have examined DNA methylation and follicle dynamics following exposure to environmental toxicants (Nilsson et al., 2012; Zhang et al., 2014); and initial assessment of

\section{REFERENCES}

Aboura, A., Dupas, C., Tachdjian, G., Portnoï, M. F., Bourcigaux, N., Dewailly, D., et al. (2009). Array comparative genomic hybridization profiling analysis reveals deoxyribonucleic acid copy number variations associated with premature ovarian failure. J. Clin. Endocrinol. Metab. 94, 4540-4546. doi: 10.1210/jc.20090186

Adhikari, D., Flohr, G., Gorre, N., Shen, Y., Yang, H., Lundin, E., et al. (2009). Disruption of Tsc2 in oocytes leads to overactivation of the entire pool of primordial follicles. Mol. Hum. Reprod. 15, 765-770. doi: 10.1093/molehr/ gap092

Adhikari, D., and Liu, K. (2009). Molecular mechanisms underlying the activation of mammalian primordial follicles. Endocr. Rev. 30, 438-464. doi: 10.1210/ er.2008-0048

Adhikari, D., Zheng, W., Shen, Y., Gorre, N., Hämäläinen, T., Cooney, A. J., et al. (2010). Tsc/mTORC1 signaling in oocytes governs the quiescence and activation of primordial follicles. Hum. Mol. Genet. 19, 397-410. doi: 10.1093/hmg/ ddp 483

Agoulnik, A. I., Lu, B., Zhu, Q., Truong, C., Ty, M. T., Arango, N., et al. (2002). A novel gene, Pog, is necessary for primordial germ cell proliferation in the mouse and underlies the germ cell deficient mutation, gcd. Hum. Mol. Genet. 11, 3047-3053. doi: 10.1093/hmg/11.24.3047

Aittomaki, K., Lucena, J. L. D., Pakarinen, P., Sistonen, P., Tapanaine, J., Gromoll, J., et al. (1995). Mutation in the follicle-stimulating hormone receptor gene causes hereditary hypergonadotropic ovarian failure. Cell 82, 959-968. doi: 10.1016/0092-8674(95)90275-9

American College of Obstetricians and Gynecologists (ACOG). (2015). Ovarian reserve testing. Obstet. Gynecol. 125, 268-273. doi: 10.1097/01.AOG. 0000459864.68372.ec

Aravin, A. A., Sachidanandam, R., Girard, A., Fejes-Toth, K., and Hannon, G. J. (2007). Developmentally regulated piRNA clusters implicate MILI in transposon control. Science 316, 744-747. doi: 10.1126/science.1142612

Atchison, F. W., Capel, B., and Means, A. R. (2003). Pin1 regulates the timing of mammalian primordial germ cell proliferation. Development 130, 3579-3586. doi: $10.1242 /$ dev.00584

Baker, T. G. (1963). A quantitative and cytological study of germ cells in human ovaries. Proc. R. Soc. Lond. B Biol. Sci. 158, 417-433. doi: 10.1098/rspb.1963.0055 the epigenome has been analyzed for the effect of maternal aging on oocyte quality (Ge et al., 2015). But, the effect of differential DNA methylation or histone modifications on the OR during the reproductive lifespan remains to be analyzed. A related issue that is also open for more extensive study is the effect and interaction of the more universal aging process with the uniquely partially programmed aging of the OR reviewed here.

The major challenge in understanding human reproduction for clinical use is the identification of reliable markers of the OR. Today AMH and AFC are routinely used to assess the size of the OR. A recent genome-wide association study has for the first time taken follicle numbers into consideration and found associations with menopause, identifying a variant in MCM8, a DNA damage response gene, as a significant effector (SchuhHuerta et al., 2012). However, again more studies are needed to find direct regulators of the OR that can be used in the clinic to help in family planning. Notably, many potentially useful targets for pharmacological intervention could provide modalities either for birth control or for the augmentation of fertility.

\section{ACKNOWLEDGMENTS}

This research was supported by the Intramural Research Program of the National Institute on Aging, NIH.

Barlow, C., Liyanage, M., Moens, P. B., Tarsounas, M., Nagashima, K., Brown, K., et al. (1998). Atm deficiency results in severe meiotic disruption as early as leptonema of prophase I. Development 125, 4007-4017.

Bedell, M. A., Brannan, C. I., Evans, E. P., Copeland, N. G., Jenkins, N. A., and Donovan, P. J. (1995). DNA rearrangements located over $100 \mathrm{~kb} 5^{\prime}$ of the Steel (Sl)-coding region in Steel-panda and Steel-contrasted mice deregulate Sl expression and cause female sterility by disrupting ovarian follicle development. Genes Dev. 9, 455-470. doi: 10.1101/gad.9.4.455

Bell, S. M., Schreiner, C. M., Hess, K. A., Anderson, K. P., and Scott, W. J. (2003). Asymmetric limb malformations in a new transgene insertional mutant, footless. Mech. Dev. 120, 597-605. doi: 10.1016/S0925-4773(03)00021-2

Bendsen, E., Byskov, A. G., Andersen, C. Y., and Westergaard, L. G. (2006). Number of germ cells and somatic cells in human fetal ovaries during the first weeks after sex differentiation. Hum. Reprod. 21, 30-35. doi: 10.1093/humrep/ dei280

Benedict, J. C., Lin, T. M., Loeffler, I. K., Peterson, R. E., and Flaws, J. A. (2000). Physiological role of the aryl hydrocarbon receptor in mouse ovary development. Toxicol. Sci. 56, 382-388. doi: 10.1093/toxsci/56.2.382

Bergeron, L., Perez, G. I., Macdonald, G., Shi, L., Sun, Y., Jurisicova, A., et al. (1998). Defects in regulation of apoptosis in caspase-2-deficient mice. Genes Dev. 12, 1304-1314. doi: 10.1101/gad.12.9.1304

Besmer, P., Manova, K., Duttlinger, R., Huang, E. J., Packer, A., Gyssler, C., et al. (1993). The kit-ligand (steel factor) and its receptor c-kit/W: pleiotropic roles in gametogenesis and melanogenesis. Dev. Suppl. 119, 125-137.

Bhangoo, A., Buyuk, E., Oktay, K., and Ten, S. (2007). Phenotypic features of 46, XX females with StAR protein mutations. Pediatr. Endocrinol. Rev. 5, 633-641.

Bierkamp, C., Luxey, M., Metchat, A., Audouard, C., Dumollard, R., and Christians, E. (2010). Lack of maternal Heat Shock Factor 1 results in multiple cellular and developmental defects, including mitochondrial damage and altered redox homeostasis, and leads to reduced survival of mammalian oocytes and embryos. Dev. Biol. 339, 338-353. doi: 10.1016/j.ydbio.2009. 12.037

Bione, S., Sala, C., Manzini, C., Arrigo, G., Zuffardi, O., Banfi, S., et al. (1998). A human homologue of the Drosophila melanogaster diaphanous gene is disrupted in a patient with premature ovarian failure: evidence for conserved function in oogenesis and implications for human sterility. Am. J. Hum. Genet. 62, 533-541. doi: $10.1086 / 301761$ 
Block, E. (1952). Quantitative morphological investigations of the follicular system in women; variations at different ages. Acta Anat. 14, 108-123. doi: $10.1159 / 000140595$

Block, E. (1953). Quantitative morphological investigations of the follicular system in newborn female infants. Acta Anat. 17, 201-206. doi: 10.1159/000140805

Bonomi, M., Somigliana, E., Cacciatore, C., Busnelli, M., Rossetti, R., Italian Network for the study of Ovarian Dysfunctions, et al. (2012). Blood cell mitochondrial DNA content and premature ovarian aging. PLOS ONE 7:e42423. doi: 10.1371/journal.pone.0042423

Bouilly, J., Bachelot, A., Broutin, I., Touraine, P., and Binart, N. (2011). Novel NOBOX loss-of-function mutations account for $6.2 \%$ of cases in a large primary ovarian insufficiency cohort. Hum. Mutat. 32, 1108-1113. doi: 10.1002/humu.21543

Bretherick, K. L., Hanna, C. W., Currie, L. M., Fluker, M. R., Hammond, G. L., and Robinson, W. P. (2008). Estrogen receptor $\alpha$ gene polymorphisms are associated with idiopathic premature ovarian failure. Fertil. Steril. 89, 318-324. doi: 10.1016/j.fertnstert.2007.03.008

Bristol-Gould, S. K., Kreeger, P. K., Selkirk, C. G., Kilen, S. M., Cook, R. W., Kipp, J. L., et al. (2006). Postnatal regulation of germ cells by activin: the establishment of the initial follicle pool. Dev. Biol. 298, 132-148. doi: 10.1016/j.ydbio.2006. 06.025

Broekmans, F. J., Kwee, J., Hendriks, D. J., Mol, B. W., and Lambalk, C. B. (2006). A systematic review of tests predicting ovarian reserve and IVF outcome. Hum. Reprod. Update 12, 685-718. doi: 10.1093/humupd/dml034

Buehr, M., McLaren, A., Bartley, A., and Darling, S. (1993). Proliferation and migration of primordial germ cells in We/We mouse embryos. Dev. Dyn. 198, 182-189. doi: 10.1002/aja.1001980304

Burgoyne, P. S., and Baker, T. G. (1981). Oocyte depletion in XO mice and their XX sibs from 12 to 200 days post partum. J. Reprod. Fertil. 61, 207-212. doi: 10.1530/jrf.0.0610207

Burgoyne, P. S., and Baker, T. G. (1985). Perinatal oocyte loss in XO mice and its implications for the aetiology of gonadal dysgenesis in XO women. J. Reprod. Fertil. 75, 633-645. doi: 10.1530/jrf.0.0750633

Byskov, A. G. (1986). Differentiation of mammalian embryonic gonad. Physiol. Rev. $66,71-117$.

Caburet, S., Arobleda, V. A., Llano, E., Overbeek, P. A., Barbero, J. L., Oka, K., et al. (2014). Mutant cohesin in premature ovarian failure. N. Eng. J. Med. 270, 943-949. doi: 10.1056/NEJMoa1309635

Carletti, M. Z., Fiedler, S. D., and Christenson, L. K. (2010). MicroRNA 21 blocks apoptosis in mouse periovulatory granulosa cells. Biol. Reprod. 83, 286-295. doi: 10.1095/biolreprod.109.081448

Carmell, M. A., Girard, A., van de Kant, H. J., Bourc'his, D., Bestor, T. H., de Rooij, D. G., et al. (2007). MIWI2 is essential for spermatogenesis and repression of transposons in the mouse male germline. Dev. Cell 12, 503-514. doi: 10.1016/j.devcel.2007.03.001

Castrillon, D. H., Miao, L., Kollipara, R., Horner, J. W., and DePinho, R. A. (2003). Suppression of ovarian follicle activation in mice by the transcription factor Foxo3a. Science 301, 215-218. doi: 10.1126/science.1086336

Castrillon, D. H., and Wasserman, S. A. (1994). Diaphanous is required for cytokinesis in Drosophila and shares domains of similarity with the products of the limb deformity gene. Development 120, 3367-3377.

Chang, H., and Matzuk, M. M. (2001). Smad5 is required for mouse primordial germ cell development. Mech. Dev. 104, 61-67. doi: 10.1016/S0925-4773(01)00367-7

Cheng, N. C., van de Vrugt, H. J., van der Valk, M. A., Oostra, A. B., Krimpenfort, P., de Vries, Y., et al. (2000). Mice with a targeted disruption of the Fanconi anemia homolog Fanca. Hum. Mol. Genet. 9, 1805-1811. doi: 10.1093/hmg/9.12.1805

Cheng, Y., Kawamura, K., Takae, S., Deguchi, M., Yang, Q., Kuo, C., et al. (2013). Oocyte-derived R-spondin2 promotes ovarian follicle development. FASEB J. 27, 2175-2184. doi: 10.1096/fj.12-223412

Choi, Y., Yuan, D., and Rajkovic, A. (2008a). Germ cell-specific transcriptional regulator sohlh2 is essential for early mouse folliculogenesis and oocyte-specific gene expression. Biol. Reprod. 79, 1176-1182. doi: 10.1095/biolreprod.108.071217

Choi, Y., Ballow, D. J., Xin, Y., and Rajkovic, A. (2008b). Lim homeobox gene, lhx8, is essential for mouse oocyte differentiation and survival. Biol. Reprod. 79, 442-449. doi: 10.1095/biolreprod.108.069393

Conlon, R. A., Reaume, A. G., and Rossant, J. (1995). Notch1 is required for the coordinate segmentation of somites. Development 121, 1533-1545.
Cordts, E. B., Santos, A. A., Peluso, C., Bianco, B., Barbosa, C. P., and Christofolini, D. M. (2012). Risk of premature ovarian failure is associated to the PvuII polymorphism at estrogen receptor gene ESR1. J Assist. Reprod. Genet. 29, 1421-1425. doi: 10.1007/s10815-012-9884-x

Crisponi, L., Deiana, M., Loi, A., Chiappe, F., Uda, M., Amati, P., et al. (2001). The putative forkhead transcription factor FOXL2 is mutated in Blepharophimosis/ptosis/epicanthus inversus syndrome. Nat. Genet. 27, 159-166. doi: 10.1038/84781

da Fonte Kohek, M. B., Batista, M. C., Russell, A. J., Vass, K., Giacaglia, L. R., Mendonca, B. B., et al. (1998). No evidence of the inactivating mutation (C566T) in the follicle-stimulating hormone receptor gene in Brazilian women with premature ovarian failure. Fertil. Steril. 70, 565-567. doi: 10.1016/S00150282(98)00203-9

Dai, A., Sun, H., Fang, T., Zhang, Q., Wu, S., Jiang, Y., et al. (2013). MicroRNA133b stimulates ovarian estradiol synthesis by targeting Foxl2. FEBS Lett. 587, 2474-2482. doi: 10.1016/j.febslet.2013.06.023

Dang, Y., Zhao, S., Qin, Y., Han, T., Li, W., and Chen, Z. J. (2015). MicroRNA-22-3p is down-regulated in the plasma of Han Chinese patients with premature ovarian failure. Fertil. Steril. 103, 802-807. doi: 10.1016/j.fertnstert.2014.12.106

De La Fuente, R., Baumann, C., Fan, T., Schmidtmann, A., Dobrinski, I., and Muegge, K. (2006). Lsh is required for meiotic chromosome synapsis and retrotransposon silencing in female germ cells. Nat. Cell Biol. 8, 1448-1454. doi: $10.1038 /$ ncb1513

Deng, W., and Lin, H. (2002). miwi, a murine homolog of piwi, encodes a cytoplasmic protein essential for spermatogenesis. Dev. Cell 2, 819-830. doi: 10.1016/S1534-5807(02)00165-X

de Vries, L., Behar, D. M., Smirin-Yosef, P., Lagovsky, I., Tzur, S., and BaselVanagaite, L. (2014). Exome sequencing reveals SYCE1 mutation associated with autosomal recessive primary ovarian insufficiency. J. Clin. Endocrinol. Metab. 99, E2129-E2132. doi: 10.1210/jc.2014-1268

de Vries, S. S., Baart, E. B., Dekker, M., Siezen, A., de Rooij, D. G., de Boer, P., et al. (1999). Mouse MutS-like protein Msh5 is required for proper chromosome synapsis in male and female meiosis. Genes Dev. 13, 523-531. doi: 10.1101/gad.13.5.523

Dierich, A., Sairam, M. R., Monaco, L., Fimia, G. M., Gansmuller, A., LeMeur, M., et al. (1998). Impairing follicle-stimulating hormone (FSH) signaling in vivo: targeted disruption of the FSH receptor leads to aberrant gametogenesis and hormonal imbalance. Proc. Natl. Acad. Sci. U.S.A. 95, 13612-13617. doi: 10.1073/pnas.95.23.13612

Di Pasquale, E., Beck-Peccoz, P., and Persani, L. (2004). Hypergonadotropic ovarian failure associated with an inherited mutation of human bone morphogenetic protein-15 (BMP15) gene. Am. J. Hum. Genet. 75, 106-111. doi: 10.1086/ 422103

Dissen, G. A., Romero, C., Hirshfield, A. N., and Ojeda, S. R. (2001). Nerve growth factor is required for early follicular development in the mammalian ovary. Endocrinology 142, 2078-2086. doi: 10.1210/en.142.5.2078

Dixit, H., Deendayal, M., and Singh, L. (2004). Mutational analysis of the mature peptide region of inhibin genes in Indian women with ovarian failure. Hum. Reprod. 19, 1760-1764. doi: 10.1093/humrep/deh342

Dixit, H., Rao, L. K., Padmalatha, V., Kanakavalli, M., Deenadayal, M., and Gupta, N. (2005). Mutational screening of the coding region of growth differentiation factor 9 gene in Indian women with ovarian failure. Menopause 12, 749-754. doi: 10.1097/01.gme.0000184424.96437.7a

Dixit, H., Rao, L. K., Padmalatha, V. V., Kanakavalli, M., Deenadayal, M., Gupta, N., et al. (2006). Missense mutations in the BMP15 gene are associated with ovarian failure. Hum. Genet. 119, 408-415. doi: 10.1007/s00439-006-0150-0

Doherty, E., Pakarinen, P., Tiitinen, A., Kiilavuori, A., Huhtaniemi, I., Forrest, S., et al. (2002). Novel mutation in the FSH receptor inhibiting signal transduction and causing primary ovarian failure. J. Clin. Endocrinol. Metab. 87, 1151-1155. doi: $10.1210 /$ jcem.87.3.8319

Dong, J., Albertini, D. F., Nishimori, K., Kumar, T. R., Lu, N., and Matzuk, M. M. (1996). Growth differentiation factor-9 is required during early ovarian folliculogenesis. Nature 383, 531-535. doi: 10.1038/383531a0

Du, J. W., Tao, X. R., Xu, K. Y., Fang, L. Y., and Qi, X. L. (2011). Polymorphisms in estrogen receptor- $\alpha$ are associated with idiopathic female infertility. Mol. Med. Rep. 4, 1239-1242. doi: 10.3892/mmr.2011.551

Duncan, A. J., Knight, J. A., Costello, H., Conway, G. S., and Rahman, S. (2012). POLG mutations and age at menopause. Hum. Reprod. 27, 2243-2244. doi: 10.1093/humrep/des130 
Durlinger, A. L., Visser, J. A., and Themmen, A. P. (2002a). Regulation of ovarian function: the role of anti-Müllerian hormone. Reproduction 124, 601-609. doi: 10.1530/rep.0.1240601

Durlinger, A. L., Gruijters, M. J., Kramer, P., Karels, B., Ingraham, H. A., Nachtigal, M. W., et al. (2002b). Anti-Mullerian hormone inhibits initiation of primordial follicle growth in the mouse ovary. Endocrinology 143, 1076-1084.

Durlinger, A. L., Gruijters, M. J., Kramer, P., Karels, B., Kumar, T. R., Matzuk, M. M., et al. (2001). Anti-Mullerian hormone attenuates the effects of FSH on follicle development in the mouse ovary. Endocrinology 142, 4891-4899. doi: 10.1210/endo.142.11.8486

Durlinger, A. L., Kramer, P., Karels, B., de Jong, F. H., Uilenbroek, J. T., Grootegoed, J. A., et al. (1999). Control of primordial follicle recruitment by anti-Mullerian hormone in the mouse ovary. Endocrinology 140, 5789-5796. doi: 10.1210/en.140.12.5789

Elvin, J. A., Yan, C., Wang, P., Nishimori, K., and Matzuk, M. M. (1999). Molecular characterization of the follicle defects in the growth differentiation factor 9deficient ovary. Mol. Endocrinol. 13, 1018-1034. doi: 10.1210/mend.13.6.0309

Fan, H. Y., Liu, Z., Johnson, P. F., and Richards, J. S. (2011). CCAAT/enhancerbinding proteins (C/EBP) $-\alpha$ and $-\beta$ are essential for ovulation, luteinization, and the expression of key target genes. Mol. Endocrinol. 25, 253-268. doi: 10.1210/me.2010-0318

Fan, H. Y., Liu, Z., Shimada, M., Sterneck, E., Johnson, P. F., Hedrick, S. M., et al. (2009). MAPK3/1 (ERK1/2) in ovarian granulosa cells are essential for female fertility. Science 324, 938-941. doi: 10.1126/science.1171396

Fan, H. Y., Shimada, M., Liu, Z., Cahill, N., Noma, N., Wu, Y., et al. (2008). Selective expression of KrasG12D in granulosa cells of the mouse ovary causes defects in follicle development and ovulation. Development 135, 2127-2137. doi: 10.1242/dev.020560

Fiedler, S. D., Carletti, M. Z., Hong, X., and Christenson, L. K. (2008). Hormonal regulation of MicroRNA expression in periovulatory mouse mural granulosa cells. Biol. Reprod. 79, 1030-1037. doi: 10.1095/biolreprod.108.069690

Finch, A., Valentini, A., Greenblatt, E., Lynch, H. T., Ghadirian, P., Armel, S., et al. (2013). Frequency of premature menopause in women who carry a BRCA1 or BRCA2 mutation. Fertil. Steril. 99, 1724-1728. doi: 10.1016/j.fertnstert.2013.01.109

Findlay, J. K., Hutt, K. J., Hickey, M., and Anderson, R. A. (2015). What is the “ovarian reserve"? Fertil. Steril. 103, 628-630. doi: 10.1016/j.fertnstert.2014. 10.037

Flaws, J. A., Hirshfield, A. N., Hewitt, J. A., Babus, J. K., and Furth, P. A. (2001). Effect of bcl-2 on the primordial follicle endowment in the mouse ovary. Biol. Reprod. 64, 1153-1159. doi: 10.1095/biolreprod64.4.1153

Forabosco, A., and Sforza, C. (2007). Establishment of ovarian reserve: a quantitative morphometric study of the developing human ovary. Fertil. Steril. 88, 675-683. doi: 10.1016/j.fertnstert.2006.11.191

Freiman, R. N., Albright, S. R., Zheng, S., Sha, W. C., Hammer, R. E., and Tjian, R. (2001). Requirement of tissue-selective TBP-associated factor TAFII105 in ovarian development. Science 293, 2084-2087. doi: 10.1126/science.1061935

Fujimoto, T., Miyayama, Y., and Fuyuta, M. (1977). The origin, migration and fine morphology of human primordial germ cells. Anat. Rec. 188, 315-330. doi: 10.1002/ar.1091880305

Gallardo, T. D., John, G. B., Bradshaw, K., Welt, C., Reijo-Pera, R., Vogt, P. H., et al. (2008). Sequence variation at the human FOXO3 locus: a study of premature ovarian failure and primary amenorrhea. Hum. Reprod. 23, 216-221. doi: 10.1093/humrep/dem255

Garcia-Ortiz, J. E., Pelosi, E., Omari, S., Nedorezov, T., Piao, Y., Karmazin, J., et al. (2009). Foxl2 functions in sex determination and histogenesis throughout mouse ovary development. BMC Dev. Biol. 9, 36. doi: 10.1186/1471213X-9-36

Gawriluk, T. R., Hale, A. N., Flaws, J. A., Dillon, C. P., Green, D. R., and Rucker, E. B. III. (2011). Autophagy is a cell survival program for female germ cells in the murine ovary. Reproduction 141, 759-765. doi: 10.1530/REP-10-0489

Ge, Z. J., Schatten, H., Zhang, C. L., and Sun, Q. Y. (2015). Oocyte ageing and epigenetics. Reproduction 149, R103-R114. doi: 10.1530/rep-14-0242

Georgiou, I., Noutsopoulos, D., Dimitriadou, E., Markopoulos, G., Apergi, A., Lazaros, L., et al. (2009). Retrotransposon RNA expression and evidence for retrotransposition events in human oocytes. Hum. Mol. Genet. 18, 1221-1228. doi: 10.1093/hmg/ddp022

Ginsburg, M., Snow, M. H., and McLaren, A. (1990). Primordial germ cells in the mouse embryo during gastrulation. Development 110, 521-528.
Gondos, B., Westergaard, L., and Byskov, A. G. (1986). Initiation of oogenesis in the human fetal ovary: ultrastructural and squash preparation study. Am. J. Obstet. Gynecol. 155, 189-195. doi: 10.1016/0002-9378(86)90109-2

Gougeon, A. (1986). Dynamics of follicular growth in the human: a model from preliminary results. Hum. Reprod. 1, 81.

Gougeon, A., Ecochard, R., and Thalabard, J. C. (1994). Age-related changes of the population of human ovarian follicles: increase in the disappearance rate of nongrowing and early-growing follicles in aging women. Biol. Reprod. 50, 653-663. doi: 10.1095/biolreprod50.3.653

Greenfeld, C. R., Pepling, M. E., Babus, J. K., Furth, P. A., and Flaws, J. A. (2007). BAX regulates follicular endowment in mice. Reproduction 133, 865-876. doi: 10.1530/REP-06-0270

Halperin, J., Devi, Y. S., Elizur, S., Stocco, C., Shehu, A., Rebourcet, D., et al. (2008). Prolactin signaling through the short form of its receptor represses forkhead transcription factor FOXO3 and its target gene galt causing a severe ovarian defect. Mol. Endocrinol. 22, 513-522. doi: 10.1210/me.20070399

Hansen, K. R., Knowlton, N. S., Thyer, A. C., Charleston, J. S., Soules, M. R., and Klein, N. A. (2008). A new model of reproductive aging: the decline in ovarian non-growing follicle number from birth to menopause. Hum. Reprod. 23, 699-708. doi: 10.1093/humrep/dem408

Haraguchi, S., Tsuda, M., Kitajima, S., Sasaoka, Y., Nomura-Kitabayashid, A., Kurokawa, K., et al. (2003). Nanos1: a mouse nanos gene expressed in the central nervous system is dispensable for normal development. Mech. Dev. 120, 721-731. doi: 10.1016/S0925-4773(03)00043-1

Harris, S. E., Chand, A. L., Winship, I. M., Gersak, K., Nishi, Y., Yanase, T., et al. (2005). INHA promoter polymorphisms are associated with premature ovarian failure. Mol. Hum. Reprod. 11, 779-784. doi: 10.1093/molehr/ gah219

He, C., Kraft, P., Chasman, D. I., Buring, J. E., Chen, C., Hankinson, S. E., et al. (2010). A large-scale candidate gene association study of age at menarche and age at natural menopause. Hum. Genet. 128, 515-527. doi: 10.1007/s00439-0100878-4

Henderson, S. A., and Edwards, R. G. (1968). Chiasma frequency and maternal age in mammals. Nature 218, 22-28. doi: 10.1038/218022a0

Hirshfield, A. N. (1991). Development of follicles in the mammalian ovary. Int. Rev. Cytol. 124, 43-101. doi: 10.1016/S0074-7696(08)61524-7

Hrabĕ de Angelis, M., McIntyre, J. II, and Gossler, A. (1997). Maintenance of somite borders in mice requires the Delta homologue DII1. Nature 386, 717-721. doi: $10.1038 / 386717 \mathrm{a} 0$

Hsieh, M., Thao, K., and Conti, M. (2011). Genetic dissection of epidermal growth factor receptor signaling during luteinizing hormone-induced oocyte maturation. PLoS ONE 6:e21574. doi: 10.1371/journal.pone.0021574

Hu, W., Gauthier, L., Baibakov, B., Jimenez-Movilla, M., and Dean, J. (2010). FIGLA, a basic helix-loop-helix transcription factor, balances sexually dimorphic gene expression in postnatal oocytes. Mol. Cell. Biol. 30, 3661-3671. doi: 10.1128/MCB.00201-10

Huang, E. J., Manova, K., Packer, A. I., Sanchez, S., Bachvarova, R. F., and Besmer, P. (1993). The murine steel panda mutation affects kit ligand expression and growth of early ovarian follicles. Dev. Biol. 157, 100-109. doi: 10.1006/dbio.1993. 1115

Jiang, M., Aittomäki, K., Nilsson, C., Pakarinen, P., Iitiä, A., Torresani, T., et al. (1998a). The frequency of an inactivating point mutation $\left({ }^{566} \mathrm{C} \rightarrow \mathrm{T}\right)$ of the human follicle-stimulating hormone receptor gene in four populations using allele-specific hybridization and time-resolved fluorometry. J. Clin. Endocrinol. Metab. 83, 4338-4343. doi: 10.1210/jc.83.12.4338

Jiang, R., Lan, Y., Chapman, H. D., Shawber, C., Norton, C. R., Serreze, D. V., et al. (1998b). Defects in limb, craniofacial, and thymic development in Jagged2 mutant mice. Genes Dev. 12, 1046-1057. doi: 10.1101/gad.12.7.1046

John, G. B., Gallardo, T. D., Shirley, L. J., and Castrillon, D. H. (2008). Foxo3 is a PI3K-dependent molecular switch controlling the initiation of oocyte growth. Dev. Biol. 321, 197-204. doi: 10.1016/j.ydbio.2008.06.017

Juneja, S. C., Barr, K. J., Enders, G. C., and Kidder, G. M. (1999). Defects in the germ line and gonads of mice lacking connexin43. Biol. Reprod. 60, 1263-1270. doi: 10.1095/biolreprod60.5.1263

Kashimada, K., Svingen, T., Feng, C. W., Pelosi, E., Bagheri-Fam, S., Harley, V. R., et al. (2011a). Antagonistic regulation of Cyp26b1 by transcription factors SOX9/SF1 and FOXL2 during gonadal development in mice. FASEB J. 25, 3561-3569. doi: 10.1096/fj.11-184333 
Kashimada, K., Pelosi, E., Chen, H., Schlessinger, D., Wilhelm, D., and Koopman, P. (2011b). FOXL2 and BMP2 act cooperatively to regulate follistatin gene expression during ovarian development. Endocrinology 152, 272-280. doi: 10.1210/en.2010-0636

Kasippilai, T., MacArthur, D. G., Kirby, A., Thomas, B., Lambalk, C. B., Daly, M. J., et al. (2013). Mutations in eIF4ENIF1 area associated with primary ovarian insufficiency. J. Clin. Endorinol. Metab. 98, E1534-E1539. doi: 10.1210/jc.20131102

Kawamura, K., Cheng, Y., Suzuki, N., Deguchi, M., Sato, Y., Takae, S., et al. (2013). Hippo signaling disruption and Akt stimulation of ovarian follicles for infertility treatment. Proc. Natl. Acad. Sci. U.S.A. 110, 17474-17479. doi: 10.1073/pnas.1312830110

Kehler, J., Tolkunova, E., Koschorz, B., Pesce, M., Gentile, L., Boiani, M., et al. (2004). Oct4 is required for primordial germ cell survival. EMBO Rep. 5, 1078-1083. doi: 10.1038/sj.embor.7400279

Kerr, C. L., Hill, C. M., Blumenthal, P. D., and Gearhart, J. D. (2008). Expression of pluripotent stem cell markers in the human fetal ovary. Hum. Reprod. 23, 589-599.

Kerr, B., Garcia-Rudaz, C., Dorfman, M., Paredes, A., and Ojeda, S. R. (2009). NTRK1 and NTRK2 receptors facilitate follicle assembly and early follicular development in the mouse ovary. Reproduction 138, 131-140. doi: 10.1530/REP08-0474

Kerr, J. B., Myers, M., and Anderson, R. A. (2013). The dynamics of the primordial follicle reserve. Reproduction 146, R205-R215. doi: 10.1530/rep-13-0181

Kimura, F., Bonomi, L. M., and Schneyer, A. L. (2011). Follistatin regulates germ cell nest breakdown and primordial follicle formation. Endocrinology 152, 697-706. doi: 10.1210/en.2010-0950

Kiyosu, C., Tsuji, T., Yamada, K., Kajita, S., and Kunieda, T. (2012). NPPC/NPR2 signaling is essential for oocyte meiotic arrest and cumulus oophorus formation during follicular development in the mouse ovary. Reproduction 144, 187-193. doi: 10.1530/REP-12-0050

Kneitz, B., Cohen, P. E., Avdievich, E., Zhu, L., Kane, M. F., Hou, H. Jr., et al. (2000). MutS homolog 4 localization to meiotic chromosomes is required for chromosome pairing during meiosis in male and female mice. Genes Dev. 14, 1085-1097.

Kobayashi, S., Yamada, M., Asaoka, M., and Kitamura, T. (1996). Essential role of the posterior morphogen nanos for germline development in Drosophila. Nature 380, 708-711. doi: $10.1038 / 380708 \mathrm{a} 0$

Koomen, M., Cheng, N. C., van de Vrugt, H. J., Godthelp, B. C., van der Valk, M. A., Oostra, A. B., et al. (2002). Reduced fertility and hypersensitivity to mitomycin C characterize Fancg/Xrcc9 null mice. Hum. Mol. Genet. 11, 273-281. doi: $10.1093 / \mathrm{hmg} / 11.3 .273$

Kotsopoulos, J., Librach, C. L., Lubinski, J., Gronwald, J., Kim-Sing, C., Ghadirian, P., et al. (2008). Infertility, treatment of infertility, and the risk of breast cancer among women with BRCA1 and BRCA2 mutations: a case-control study. Cancer Causes Control 19, 1111-1119. doi: 10.1007/s10552-008-9175-0

Kovanci, E., Rohozinski, J., Simpson, J. L., Heard, M. J., Bishop, C. E., and Carson, S. A. (2007). Growth differentiating factor-9 mutations may be associated with premature ovarian failure. Fertil. Steril. 87, 143-146. doi: 10.1016/j.fertnstert.2006.05.079

Kuang, H., Han, D., Xie, J., Yan, Y., Li, J., and Ge, P. (2014). Profiling of differentially expressed microRNAs in premature ovarian failure in an animal model. Gynecol. Endocrinol. 30, 57-61. doi: 10.3109/09513590.2013.850659

Kumar, T. R., Wang, Y., Lu, N., and Matzuk, M. M. (1997). Follicle stimulating hormone is required for ovarian follicle maturation but not male fertility. Nat. Genet. 15, 201-204. doi: 10.1038/ng0297-201

Kuramochi-Miyagawa, S., Kimura, T., Ijiri, T. W., Isobe, T., Asada, N., Fujita, Y., et al. (2004). Mili, a mammalian member of piwi family gene, is essential for spermatogenesis. Development 131, 839-849. doi: 10.1242/dev.00973

Kurilo, L. F. (1981). Oogenesis in antenatal development in man. Hum. Genet. 57, 86-92. doi: 10.1007/BF00271175

Lacombe, A., Lee, H., Zahed, L., Choucair, M., Muller, J. M., Nelson, S. F., et al. (2006). Disruption of POF1B binding to nonmuscle actin filaments is associated with premature ovarian failure. Am. J. Hum. Genet. 79, 113-119. doi: $10.1086 / 505406$

Laissue, P., Christin-Maitre, S., Touraine, P., Kuttenn, F., Ritvos, O., Aittomaki, K., et al. (2006). Mutations and sequence variants in GDF9 and BMP15 in patients with premature ovarian failure. Eur. J. Endocrinol. 154, 739-744. doi: 10.1530/eje.1.02135
Lambalk, C. B., de Koning, C. H., Flett, A., Van Kasteren, Y., Gosden, R., and Homburg, R. (2004). Assessment of ovarian reserve. Ovarian biopsy is not a valid method for the prediction of ovarian reserve. Hum. Reprod. 19, 1055-1059. doi: 10.1093/humrep/deh216

Lass, A. (2004). Assessment of ovarian reserve. Is there still a role for ovarian biopsy in the light of new data? Hum. Reprod. 19, 467-469. doi: 10.1093/humrep/deh118

Lawson, K. A., Dunn, N. R., Roelen, B. A., Zeinstra, L. M., Davis, A. M., Wright, C. V., et al. (1999). Bmp4 is required for the generation of primordial germ cells in the mouse embryo. Genes Dev. 13, 424-436. doi: 10.1101/gad.13.4.424

Layman, L. C., Shelley, M. E., Huey, L. O., Wall, S. W., Tho, S. P., and McDonough, P. G. (1993). Follicle-stimulating hormone beta gene structure in premature ovarian failure. Fertil. Steril. 60, 852-857.

Lee, S., Kang, D. W., Hudgins-Spivey, S., Krust, A., Lee, E. Y., Koo, Y., et al. (2009). Theca-specific estrogen receptor- $\alpha$ knockout mice lose fertility prematurely. Endocrinology 150, 3855-3862. doi: 10.1210/en.2008-1774

Lei, L., Jin, S., Gonzalez, G., Behringer, R. R., and Woodruff, T. K. (2010). The regulatory role of Dicer in folliculogenesis in mice. Mol. Cell. Endocrinol. 315, 63-73. doi: 10.1016/j.mce.2009.09.021

Li, L., Fu, Y. C., Xu, J. J., Lin, X. H., Chen, X. C., Zhang, X. M., et al. (2015). Caloric restriction promotes the reserve of follicle pool in adult female rats by inhibiting the activation of mammalian target of rapamycin signaling. Reprod. Sci. 22, 60-67. doi: 10.1177/1933719114542016

Liang, L., Soyal, S. M., and Dean, J. (1997). FIG $\alpha$, a germ cell specific transcription factor involved in the coordinate expression of the zona pellucida genes. Development 124, 4939-4949.

Lin, W. T., Beattie, M., Chen, L. M., Oktay, K., Crawford, S. L., Gold, E. B., et al. (2013). Comparison of age at natural menopause in BRCA1/2 mutation carriers with a non-clinic-based sample of women in northern California. Cancer 119, 1652-1659. doi: $10.1002 /$ cncr.27952

Lingenfelter, B. M., Tripurani, S. K., Tejomurtula, J., Smith, G. W., and Yao, J. (2011). Molecular cloning and expression of bovine nucleoplasmin 2 (NPM2): a maternal effect gene regulated by miR-181a. Reprod. Biol. Endocrinol. 9, 40. doi: $10.1186 / 1477-7827-9-40$

Lourenco, D., Brauner, R., Lin, L., De Perdigo, A., Werhha, G., Muresan, M., et al. (2009). Mutations in the NR5A1 associated with ovarian insufficiency. N. Engl. J. Med. 360, 1200-1210. doi: 10.1056/NEJMoa0806228

Lubahn, D. B., Moyer, J. S., Golding, T. S., Couse, J. F., Korach, K. S., and Smithies, O. (1993). Alteration of reproductive function but not prenatal sexual development after insertional disruption of the mouse estrogen receptor gene. Proc. Natl. Acad. Sci. U.S.A. 90, 11162-11166. doi: 10.1073/pnas.90.23.11162

Ma, T., Jiang, H., Gao, Y., Zhao, Y., Dai, L., Xiong, Q., et al. (2011). Microarray analysis of differentially expressed microRNAs in non-regressed and regressed bovine corpus luteum tissue; microRNA-378 may suppress luteal cell apoptosis by targeting the interferon gamma receptor 1 gene. J. Appl. Genet. 52, 481486. doi: 10.1007/s13353-011-0055-z

Ma, X., Dong, Y., Matzuk, M. M., and Kumar, T. R. (2004). Targeted disruption of luteinizing hormone $\beta$-subunit leads to hypogonadism, defects in gonada steroidogenesis, and infertility. Proc. Natl. Acad. Sci. U.S.A. 101, 17294-17299. doi: 10.1073/pnas.0404743101

Maheshwar, A., and Fowler, P. A. (2008). Primordial follicular assembly in humans-revisited. Zygote 16, 285-296. doi: 10.1017/S0967199408004802

Malki, S., van der Heijden, G. W., O’Donnell, K. A., Martin, S. L., and Bortvin, A. (2014). A role for retrotransposon LINE-1 in fetal oocyte attrition in mice. Dev. Cell 29, 521-533. doi: 10.1016/j.devcel.2014.04.027

Mandon-Pépin, B., Touraine, P., Kuttenn, F., Derbois, C., Rouxel, A., Matsuda, F., et al. (2008). Genetic investigation of four meiotic genes in women with premature ovarian failure. Eur. J. Endocrinol. 158, 107-115. doi: 10.1530/EJE-070400

Marozzi, A., Porta, C., Vegetti, W., Crosignani, P. G., Tibiletti, M. G., Dalprà L., et al. (2002). Mutation analysis of the inhibin alpha gene in a cohort of Italian women affected by ovarian failure. Hum. Reprod. 17, 1741-1745. doi: 10.1093/humrep/17.7.1741

Martin, J. A., Hamilton, B. E., Ventura, S. J., Osterman, M. J. K., Kirmeyer, S., Matherws, T. J., et al. (2011). "Births: final data for 2009." in National Vital Statistic Reports, Vol. 60 (Hyattsville, MD: National Center for Health Statistics), $1-71$.

Matikainen, T., Perez, G. I., Jurisicova, A., Pru, J. K., Schlezinger, J. J., Ryu, H. Y., et al. (2001). Aromatic hydrocarbon receptor-driven Bax gene expression is 
required for premature ovarian failure caused by biohazardous environmental chemicals. Nat. Genet. 28, 355-360. doi: 10.1038/ng575

Matzuk, M. M., Finegold, M. J., Su, J. G., Hsueh, A. J., and Bradley, A. (1992). $\alpha-$ Inhibin is a tumour-suppressor gene with gonadal specificity in mice. Nature 360, 313-319. doi: 10.1038/360313a0

McCright, B., Gao, X., Shen, L., Lozier, J., Lan, Y., Maguire, M., et al. (2001). Defects in development of the kidney, heart and eye vasculature in mice homozygous for a hypomorphic Notch2 mutation. Development 128, 491-502.

McGee, E. A., and Hsueh, A. J. (2000). Initial and cyclic recruitment of ovarian follicles. Endocr. Rev. 21, 200-214. doi: 10.1210/er.21.2.200

Metchat, A., Akerfelt, M., Bierkamp, C., Delsinne, V., Sistonen, L., Alexandre, H., et al. (2009). Mammalian heat shock factor 1 is essential for oocyte meiosis and directly regulates Hsp90 $\alpha$ expression. J. Biol. Chem. 284, 9521-9528. doi: 10.1074/jbc.M808819200

Michaelson-Cohen, R., Mor, P., Srebnik, N., Beller, U., Levy-Lahad, E., and Eldar-Geva, T. (2014). BRCA mutation carriers do not have compromised ovarian reserve. Int. J. Gynecol. Cancer 24, 233-237. doi: 10.1097/IGC. 0000000000000058

Miller, M. E., and Chatten, J. (1967). Ovarian changes in ataxia telangiectasia. Acta Paediatr. Scand. 56, 559-561. doi: 10.1111/j.1651-2227.1967.tb15424.x

Monniaux, D., Clément, F., Dalbiès-Tran, R., Estienne, A., Fabre, S., Mansanet, C., et al. (2014). The ovarian reserve of primordial follicles and the dynamic reserve of antral growing follicles: what is the link? Biol. Reprod. 90, 85. doi: 10.1095/biolreprod.113.117077

Monniaux, D., Huet, C., Besnard, N., Clément, F., Bosc, M., Pisselet, C., et al. (1997). Follicular growth and ovarian dynamics in mammals. J. Reprod. Fertil. Suppl. 51, 3-23.

Morita, Y., Perez, G. I., Paris, F., Miranda, S. R., Ehleiter, D., Haimovitz-Friedman, A., et al. (2000). Oocyte apoptosis is suppressed by disruption of the acid sphingomyelinase gene or by sphingosine-1-phosphate therapy. Nat. Med. 6, 1109-1114. doi: 10.1038/80442

Moslehi, R., Singh, R., Lessner, L., and Friedman, J. M. (2010). Impact of BRCA mutations on female fertility and offspring sex ratio. Am. J. Hum. Biol. 22, 201-205. doi: 10.1002/ajhb.20978

M'Rabet, N., Moffat, R., Helbling, S., Kaech, A., Zhang, H., and de Geyter, C. (2012). The CC-allele of the PvuII polymorphic variant in intron 1 of the $\alpha$-estrogen receptor gene is significantly more prevalent among infertile women at risk of premature ovarian aging. Fertil. Steril. 98, 965-972.e1-5. doi: 10.1016/j.fertnstert.2012.05.048

Murchison, E. P., Stein, P., Xuan, Z., Pan, H., Zhang, M. Q., Schultz, R. M., et al. (2007). Critical roles for Dicer in the female germline. Genes Dev. 21, 682-693. doi: 10.1101/gad.1521307

Nagaraja, A. K., Andreu-Vieyra, C., Franco, H. L., Ma, L., Chen, R., Han, D., et al. (2008). Deletion of Dicer in somatic cells of the female reproductive tract causes sterility. Mol. Endocrinol. 22, 2336-2352. doi: 10.1210/me.20080142

Nagashima, T., Kim, J., Li, Q., Lydon, J. P., DeMayo, F. J., Lyons, K. M., et al. (2011). Connective tissue growth factor is required for normal follicle development and ovulation. Mol. Endocrinol. 25, 1740-1759. doi: 10.1210/me.2011-1045

Navot, D., Rosenwaks, Z., and Margalioth, E. J. (1987). Prognostic assessment of female fecundity. Lancet 2, 645-647. doi: 10.1016/S0140-6736(87) 92439-1

Nelson, L. M. (2014). The Flat Earth Society: a rose by any other name? Hum. Reprod. 29, 190-192. doi: 10.1093/humrep/det443

Nichols, J., Zevnik, B., Anastassiadis, K., Niwa, H., Klewe-Nebenius, D., Chambers, I., et al. (1998). Formation of pluripotent stem cells in the mammalian embryo depends on the POU transcription factor Oct4. Cell 95, 379-391. doi: 10.1016/S0092-8674(00)81769-9

Nilsson, E., Dole, G., and Skinner, M. K. (2009). Neurotrophin NT3 promotes ovarian primordial to primary follicle transition. Reproduction 138, 697-707. doi: 10.1530/REP-09-0179

Nilsson, E., Larsen, G., Manikkam, M., Guerrero-Bosagna, C., Savenkova, M. I., and Skinner, M. K. (2012). Environmentally induced epigenetic transgenerational inheritance of ovarian disease. PLOS ONE 7:e36129. doi: 10.1371/journal.pone.0036129

Norling, A., Hirschberg, A. L., Karlsson, L., Rodriguez-Wallberg, K. A., Iwarsson, E., Wedell, A., et al. (2014). No mutations in the PSMC3IP gene identified in a Swedish cohort of women with primary ovarian insufficiency. Sex. Dev. 8, 146-150. doi: 10.1159/000357605
Ohinata, Y., Payer, B., O'Carroll, D., Ancelin, K., Ono, Y., Sano, M., et al. (2005). Blimp1 is a critical determinant of the germ cell lineage in mice. Nature 436, 207-213. doi: 10.1038/nature03813

Oktay, K., Kim, J. Y., Barad, D., and Babayev, S. N. (2010). Association of BRCA1 mutations with occult primary ovarian insufficiency: a possible explanation for the link between infertility and breast/ovarian cancer risks. J. Clin. Oncol. 28, 240-244. doi: 10.1200/JCO.2009.24.2057

Omari, S., Waters, M., Naranian, T., Kim, K., Perumalsamy, A. L., Chi, M., et al. (2015). Mcl-1 is a key regulator of the ovarian reserve. Cell Death Dis. 6, e1755. doi: $10.1038 /$ cddis. 2015.95

Ortega, S., Prieto, I., Odajima, J., Martín, A., Dubus, P., Sotillo, R., et al. (2003). Cyclin-dependent kinase 2 is essential for meiosis but not for mitotic cell division in mice. Nat. Genet. 35, 25-31. doi: 10.1038/ng1232

Otsuka, M., Zheng, M., Hayashi, M., Lee, J. D., Yoshino, O., Lin, S., et al. (2008). Impaired microRNA processing causes corpus luteum insufficiency and infertility in mice. J. Clin. Invest. 118, 1944-1954. doi: 10.1172/JCI33680

Ottolenghi, C., Pelosi, E., Tran, J., Colombino, M., Douglass, E., Nedorezov, T., et al. (2007). Loss of Wnt 4 and Foxl2 leads to female-to-male sex reversal extending to germ cells. Hum. Mol. Genet. 23, 2795-2804. doi: 10.1093/hmg/ $\operatorname{ddm} 235$

Ottolenghi, C., Uda, M., Hamatani, T., Crisponi, L., Garcia, J. E., Ko, M., et al. (2004). Aging of oocyte, ovary, and human reproduction. Ann. N. Y. Acad. Sci. 1034, 117-131. doi: 10.1196/annals.1335.015

Pal, T., Keefe, D., Sun, P., Narod, S. A., and Hereditary Breast Cancer Clinical Study Group. (2010). Fertility in women with BRCA mutations: a case-control study. Fertil. Steril. 93, 1805-1808. doi: 10.1016/j.fertnstert.2008.12.052

Pangas, S. A., Choi, Y., Ballow, D. J., Zhao, Y., Westphal, H., Matzuk, M. M., et al. (2006). Oogenesis requires germ cell-specific transcriptional regulators Sohlh1 and Lhx8. Proc. Natl. Acad. Sci. U.S.A. 103, 8090-8095. doi: 10.1073/pnas.0601083103

Park, M., Jeon, S., Jeong, J. H., Park, M., Lee, D. R., Yoon, T. K., et al. (2012). Identification and characterization of LHX8 DNA binding elements. Dev. Reprod. 16, 379-384. doi: 10.12717/DR.2012.16.4.379

Pelosi, E., Forabosco, A., and Schlessinger, D. (2011). Germ cell formation from embryonic stem cells and the use of somatic cell nuclei in oocytes. Ann. N. Y. Acad. Sci. 1221, 18-26. doi: 10.1111/j.1749-6632.2011.05982.x

Pelosi, E., Omari, S., Michel, M., Ding, J., Amano, T., Forabosco, A., et al. (2013). Constitutively active Foxo3 in oocytes preserves ovarian reserve in mice. Nat. Commun. 4, 1843. doi: 10.1038/ncomms2861

Pelosi, E., Simonsick, E., Forabosco, A., Garcia-Ortiz, J. E., and Schlessinger, D. (2015). Dynamics of the ovarian reserve and impact of genetic and epidemiological factors on age of menopause. Biol. Reprod. 92, 130. doi: 10.1095/biolreprod.114.127381

Pepling, M. E. (2012). Follicular assembly: mechanisms of action. Reproduction 143 , 139-149. doi: 10.1530/REP-11-0299

Perez, G. I., Robles, R., Knudson, C. M., Flaws, J. A., Korsmeyer, S. J., and Tilly, J. L. (1999). Prolongation of ovarian lifespan into advanced chronological age by Bax-deficiency. Nat. Genet. 21, 200-203. doi: 10.1038/5985

Pittman, D. L., Cobb, J., Schimenti, K. J., Wilson, L. A., Cooper, D. M., Brignull, E., et al. (1998). Meiotic prophase arrest with failure of chromosome synapsis in mice deficient for Dmc1, a germline-specific RecA homolog. Mol. Cell 1, 697-705. doi: 10.1016/S1097-2765(00)80069-6

Qin, Y., Choi, Y., Zhao, H., Simpson, J. L., Chen, Z. J., and Rajkovic, A. (2007). NOBOX homeobox mutation causes premature ovarian failure. Am. J. Hum. Genet. 81, 576-581. doi: 10.1086/519496

Qin, Y., Jiao, X., Dalgleish, R., Vujovic, S., Li, J., Simpson, J. L., et al. (2014). Novel variants in the SOHLH2 gene are implicated in human premature ovarian failure. Fertil. Steril. 101, 1104-1109. doi: 10.1016/j.fertnstert.2014.01.001

Qin, Y., Zhao, H., Kovanci, E., Simpson, J. L., Chen, Z. J., and Rajkovic, A. (2008). Analysis of LHX8 mutation in premature ovarian failure. Fertil. Steril. 89, 1012-1014. doi: 10.1016/j.fertnstert.2007.04.017

Rah, H., Jeon, Y. J., Shim, S. H., Cha, S. H., Choi, D. H., Kwon, H., et al. (2013). Association of miR-146aC $>$ G, miR-196a2T $>C$, and miR-499A $>$ G polymorphisms with risk of premature ovarian failure in Korean women. Reprod. Sci. 20, 60-68. doi: 10.1177/1933719112450341

Rajareddy, S., Reddy, P., Du, C., Liu, L., Jagarlamudi, K., Tang, W., et al. (2007). p27kip1 (cyclin-dependent kinase inhibitor 1B) controls ovarian development by suppressing follicle endowment and activation and promoting follicle atresia in mice. Mol. Endocrinol. 21, 2189-2202. doi: 10.1210/me.2007-0172 
Rajkovic, A., Pangas, S. A., Ballow, D., Suzumori, N., and Matzuk, M. M. (2004). NOBOX deficiency disrupts early folliculogenesis and oocyte-specific gene expression. Science 305, 1157-1159. doi: 10.1126/science.1099755

Ratts, V. S., Flaws, J. A., Kolp, R., Sorenson, C. M., and Tilly, J. L. (1995). Ablation of bcl-2 gene expression decreases the numbers of oocytes and primordial follicles established in the postnatal female mouse gonad. Endocrinology 136, 36653668.

Reddy, P., Adhikari, D., Zheng, W., Liang, S., Hämäläinen, T., Tohonen, V., et al. (2009). PDK1 signaling in oocytes controls reproductive aging and lifespan by manipulating the survival of primordial follicles. Hum. Mol. Genet. 18, 2813-2824. doi: $10.1093 / \mathrm{hmg} / \mathrm{ddp} 217$

Reddy, P., Liu, L., Adhikari, D., Jagarlamudi, K., Rajareddy, S., Shen, Y., et al. (2008). Oocyte-specific deletion of Pten causes premature activation of the primordial follicle pool. Science 319, 611-613. doi: 10.1126/science.1152257

Reddy, P., Zheng, W., and Liu, K. (2010). Mechanisms maintaining the dormancy and survival of mammalian primordial follicles. Trends Endocrinol. Metab. 21, 96-103. doi: 10.1016/j.tem.2009.10.001

Reith, A. D., Rottapel, R., Giddens, E., Brady, C., Forrester, L., and Bernstein, A. (1990). W mutant mice with mild or severe developmental defects contain distinct point mutations in the kinase domain of the c-kit receptor. Genes Dev. 4, 390-400. doi: 10.1101/gad.4.3.390

Richardson, M. C., Guo, M., Fauser, B. C., and Macklon, N. S. (2014). Environmental and developmental origins of ovarian reserve. Hum. Reprod. Update 20, 353-369. doi: 10.1093/humupd/dmt057

Richardson, S. J., Senikas, V., and Nelson, J. F. (1987). Follicular depletion during the menopausal transition: evidence for accelerated loss and ultimate exhaustion. J. Clin. Endocrinol. Metab. 65, 1231-1237. doi: 10.1210/jcem-65-61231

Riedlinger, G., Okagaki, R., Wagner, K. U., Rucker, E. B. III, Oka, T., Miyoshi, $\mathrm{K}$., et al. (2002). Bcl-x is not required for maintenance of follicles and corpus luteum in the postnatal mouse ovary. Biol. Reprod. 66, 438-444. doi: 10.1095/biolreprod66.2.438

Romanienko, P. J., and Camerini-Otero, R. D. (2000). The mouse Spol1 gene is required for meiotic chromosome synapsis. Mol. Cell 6, 975-987. doi: 10.1016/S1097-2765(00)00097-6

Rossetti, R., Di Pasquale, E., Marozzi, A., Bione, S., Toniolo, D., Grammatico, P., et al. (2009). BMP15 mutations associated with primary ovarian insufficiency cause a defective production of bioactive protein. Hum. Mutat. 30, 804-810. doi: 10.1002/humu.20961

Rossi, E., Verri, A. P., Patricelli, M. G., Destefani, V., Ricca, I., Vetro, A., et al. (2008). A $12 \mathrm{Mb}$ deletion at $7 \mathrm{q} 33-\mathrm{q} 35$ associated with autism spectrum disorders and primary amenorrhea. Eur. J. Med. Genet. 51, 631-638. doi: 10.1016/j.ejmg.2008.06.010

Rucker, E. B. III, Dierisseau, P., Wagner, K. U., Garrett, L., Wynshaw-Boris, A., Flaws, J. A., et al. (2000). Bcl-x and Bax regulate mouse primordial germ cell survival and apoptosis during embryogenesis. Mol. Endocrinol. 14, 1038-1052. doi: 10.1210/mend.14.7.0465

Russell, E. S., Fondal, E. L., and Coulombre, J. L. (1948). Preliminary analysis of pleiotropism at the W-locus in the mouse. Genetics 33, 627.

Rzepka-Górska, I., Tarnowski, B., Chudecka-Głaz, A., Górski, B., Zielińska, D., and Tołoczko-Grabarek, A. (2006). Premature menopause in patients with BRCA1 gene mutation. Breast Cancer Res. Treat. 100, 59-63. doi: 10.1007/s10549-0069220-1

Saitou, M., and Yamaji, M. (2012). Primordial germ cells in mice. Cold Spring Harb. Perspect. Biol. 4, pii: a008375. doi: 10.1101/cshperspect.a008375

Sato, Y., Cheng, Y., Kawamura, K., Takae, S., and Hsueh, A. J. (2012). C-type natriuretic peptide stimulates ovarian follicle development. Mol. Endocrinol. 26, 1158-1166. doi: 10.1210/me.2012-1027

Schlessinger, D., Garcia-Ortiz, J. E., Forabosco, A., Uda, M., Crisponi, L., and Pelosi, E. (2010). Determination and stability of gonadal sex. J. Androl. 31, 16-25. doi: 10.2164/jandrol.109.008201

Schuh-Huerta, S. M., Johnson, N. A., Rosen, M. P., Sternfeld, B., Cedars, M. I., and Reijo Pera, R. A. (2012). Genetic markers of ovarian follicle number and menopause in women of multiple ethnicities. Hum. Genet. 131, 1709-1724. doi: 10.1007/s00439-012-1184-0

Sehested, L. T., Møller, R. S., Bache, I., Andersen, N. B., Ullmann, R., Tommerup, N., et al. (2010). Deletion of 7q34-q36.2 in two siblings with mental retardation, language delay, primary amenorrhea, and dysmorphic features. Am. J. Med. Genet. A 152A, 3115-3119. doi: 10.1002/ajmg.a.33476
Sforza, C., Ferrario, V. F., De Pol, A., Marzona, L., Forni, M., and Forabosco, A. (1993). Morphometric study of the human ovary during compartmentalization. Anat. Rec. 236, 626-634. doi: 10.1002/ar.1092360406

Sforza, C., Vizzotto, L., Ferrario, V. F., and Forabosco, A. (2003). Position of follicles in normal human ovary during definitive histogenesis. Early Hum. Dev. 74, 27-35. doi: 10.1016/S0378-3782(03)00081-1

She, Z. Y., and Yang, W. X. (2014). Molecular mechanisms involved in mammalian primary sex determination. J. Mol. Endocrinol. 53, R21-R37. doi: 10.1530/jme14-0018

Shelling, A. N., Burton, K. A., Chand, A. L., van Ee, C. C., France, J. T., Farquhar, C. M., et al. (2000). Inhibin: a candidate gene for premature ovarian failure. Hum. Reprod. 15, 2644-2649. doi: 10.1093/humrep/15.12.2644

Shen, C., Delahanty, R. J., Gao, Y. T., Lu, W., Xiang, Y. B., Zheng, Y., et al. (2013). Evaluating GWAS-identified SNPs for age at natural menopause among Chinese women. PLoS ONE 8:e58766. doi: 10.1371/journal.pone.0058766

Shen, S. X., Weaver, Z., Xu, X., Li, C., Weinstein, M., Chen, L., et al. (1998). A targeted disruption of the murine Brcal gene causes gammairradiation hypersensitivity and genetic instability. Oncogene 17,3115-3124. doi: 10.1038/sj.onc. 1202243

Shimizu, Y., Kimura, F., Takebayashi, K., Fujiwara, M., Takakura, K., and Takahashi, K. (2009). Mutational analysis of the PTEN gene in women with premature ovarian failure. Acta Obstet. Gynecol. Scand. 88, 824-825. doi: $10.1080 / 00016340902971458$

Shinoda, G., De Soysa, T. Y., Seligson, M. T., Yabuuchi, A., Fujiwara, Y., Huang, P. Y., et al. (2013). Lin28a regulates germ cell pool size and fertility. Stem Cells 31, 1001-1009. doi: 10.1002/stem.1343

Sirotkin, A. V., Kisová, G., Brenaut, P., Ovcharenko, D., Grossmann, R., and Mlyncek, M. (2014). Involvement of microRNA Mir15a in control of human ovarian granulosa cell proliferation, apoptosis, steroidogenesis, and response to FSH. Microrna 3, 29-36. doi: 10.2174/2211536603666140227232824

Sirotkin, A. V., Lauková, M., Ovcharenko, D., Brenaut, P., and Mlyncek, M. (2010). Identification of microRNAs controlling human ovarian cell proliferation and apoptosis. J. Cell. Physiol. 223, 49-56. doi: 10.1002/jcp.21999

Skinner, M. K. (2005). Regulation of primordial follicle assembly and development. Hum. Reprod. Update 11, 461-471. doi: 10.1093/humupd/dmi020

Skrzypczak, J., Pisarski, T., Biczysko, W., and Kedzia, H. (1981). Evaluation of germ cells development in gonads of human fetuses and newborns. Folia Histochem. Cytochem. (Krakow) 19, 17-024.

Smith, E. R., Yeasky, T., Wei, J. Q., Miki, R. A., Cai, K. Q., Smedberg, J. L., et al. (2012). White spotting variant mouse as an experimental model for ovarian aging and menopausal biology. Menopause 19, 588-596. doi: 10.1097/gme.0b013e318239cc53

Solovyeva, E. V., Hayashi, M., Margi, K., Barkats, C., Klein, C., Amsterdam, A., et al. (2000). Growth differentiation factor-9 stimulates rat thecainterstitial cell androgen biosynthesis. Biol. Reprod. 63, 1214-1218. doi: 10.1095/biolreprod63.4.1214

Soyal, S. M., Amleh, A., and Dean, J. (2000). FIGa, a germ-cell specific transcription factor required for ovarian follicle formation. Development 127, 4645-4654.

Spears, N., Molinek, M. D., Robinson, L. L., Fulton, N., Cameron, H., Shimoda, K., et al. (2003). The role of neurotrophin receptors in female germ-cell survival in mouse and human. Development 130, 5481-5491. doi: 10.1242/dev.00707

Spencer, K. L., Malinowski, J., Carty, C. L., Franceschini, N., FernándezRhodes, L., Young, A., et al. (2013). Genetic variation and reproductive timing: African American women from the Population Architecture using Genomics and Epidemiology (PAGE) Study. PLoS ONE 8:e55258. doi: 10.1371/journal.pone.0055258

Steiner, A. Z. (2013). Biomarkers of ovarian reserve as predictors of reproductive potential. Semin. Reprod. Med. 31, 437-442. doi: 10.1055/s-0033-1356479

Stolk, L., Perry, J. R., Chasman, D. I., He, C., Mangino, M., Sulem, P., et al. (2012). Meta-analyses identify 13 loci associated with age at menopause and highlight DNA repair and immune pathways. Nat. Genet. 44, 260-268. doi: 10.1038/ng.1051

Sundblad, V., Chiauzzi, V. A., Escobar, M. E., Dain, L., and Charreau, E. H. (2004). Screening of FSH receptor gene in Argentine women with premature ovarian failure (POF). Mol. Cell. Endocrinol. 222, 53-59. doi: 10.1016/j.mce.2004.05.002

Takasawa, K., Kashimada, K., Pelosi, E., Takagi, M., Morio, T., Asahara, H., et al. (2014). FOXL2 transcriptionally represses Sf1 expression by antagonizing WT1 during ovarian development in mice. FASEB J. 28, 2020-2028. doi: 10.1096/fj.13246108 
Tamura, N., Doolittle, L. K., Hammer, R. E., Shelton, J. M., Richardson, J. A., and Garbers, D. L. (2004). Critical roles of the guanylyl cyclase B receptor in endochondral ossification and development of female reproductive organs. Proc. Natl. Acad. Sci U.S.A. 101, 17300-17305. doi: 10.1073/pnas. 0407894101

Tarín, J. J., Brines, J., and Cano, A. (1998). Long-term effects of delayed parenthood. Hum. Reprod. 13, 2371-2376. doi: 10.1093/humrep/13.9.2371

Tarnawa, E. D., Baker, M. D., Aloisio, G. M., Carr, B. R., and Castrillon, D. H. (2013). Gonadal expression of Foxo1, but not Foxo3, is conserved in diverse Mammalian species. Biol. Reprod. 88, 103. doi: 10.1095/biolreprod.112.105791

Tay, J., and Richter, J. D. (2001). Germ cell differentiation and synaptonemal complex formation are disrupted in CPEB knockout mice. Dev. Cell 1, 201-213. doi: 10.1016/S1534-5807(01)00025-9

Thomas, F. H., and Vanderhyden, B. C. (2006). Oocyte-granulosa cell interactions during mouse follicular development: regulation of kit ligand expression and its role in oocyte growth. Reprod. Biol. Endocrinol. 4, 19. doi: 10.1186/1477-78274-19

Thomson, T., and Lin, H. (2009). The biogenesis and function of PIWI proteins and piRNAs: progress and prospect. Annu. Rev. Cell Dev. Biol. 25, 355-376. doi: 10.1146/annurev.cellbio.24.110707.175327

Tilly, J. L. (2003). Ovarian follicle counts-not as simple as 1, 2, 3. Reprod. Biol. Endocrinol. 1, 1-4. doi: 10.1186/1477-7827-1-11

Titus, S., Li, F., Stobezki, R., Akula, K., Unsal, E., Jeong, K., et al. (2013). Impairment of BRCA1-related DNA double-strand break repair leads to ovarian aging in mice and humans. Sci. Transl. Med. 5, 172ra21. doi: 10.1126/scitranslmed.3004925

Tremblay, J. J., and Viger, R. S. (2003). A mutated form of steroidogenic factor 1 (SF$1 \mathrm{G} 35 \mathrm{E})$ that causes sex reversal in humans fails to synergize with transcription factor GATA-4. J. Biol. Chem. 278, 42637-42642. doi: 10.1074/jbc.M305485200

Tremblay, K. D., Dunn, N. R., and Robertson, E. J. (2001). Mouse embryos lacking Smadl signals display defects in extra-embryonic tissues and germ cell formation. Development 128, 3609-3621.

Tripurani, S. K., Lee, K. B., Wee, G., Smith, G. W., and Yao, J. (2011). MicroRNA196a regulates bovine newborn ovary homeobox gene (NOBOX) expression during early embryogenesis. BMC Dev. Biol. 11:25. doi: 10.1186/1471-213X11-25

Trombly, D. J., Woodruff, T. K., and Mayo, K. E. (2009). Suppression of Notch signaling in the neonatal mouse ovary decreases primordial follicle formation. Endocrinology 150, 1014-1024. doi: 10.1210/en.2008-0213

Tsuda, M., Sasaoka, Y., Kiso, M., Abe, K., Haraguchi, S., Kobayashi, S., et al. (2003). Conserved role of nanos proteins in germ cell development. Science 301, 1239-1241. doi: 10.1126/science.1085222

Uda, M., Ottolenghi, C., Crisponi, L., Garcia, J. E., Deiana, M., Kimber, W., et al. (2004). Foxl2 disruption causes mouse ovarian failure by pervasive blockage of follicle development. Hum. Mol. Genet. 11, 1171-1181. doi: $10.1093 / \mathrm{hmg} / \mathrm{ddh} 124$

Uhlenhaut, N. H., Jakob, S., Anlag, K., Eisenberg, T., Sekido, R., Kress, J., et al. (2009). Somatic sex reprogramming of adult ovaries to testes by Foxl2 ablation. Cell 139, 1130-1142. doi: 10.1016/j.cell.2009.11.021

Uri-Belapolsky, S., Shaish, A., Eliyahu, E., Grossman, H., Levi, M., Chuderland, D., et al. (2014). Interleukin-1 deficiency prolongs ovarian lifespan in mice. Proc. Natl. Acad. Sci. U.S.A. 111, 12492-12497. doi: 10.1073/pnas.1323955111

Vale, W., Rivier, J., Vaughan, J., McClintock, R., Corrigan, A., Woo, W., et al. (1986), Purification and characterization of an FSH releasing protein from porcine ovarian follicular fluid. Nature 321, 776-779. doi: 10.1038/321776a0

Valentini, A., Finch, A., Lubinski, J., Byrski, T., Ghadirian, P., Kim-Sing, C., et al. (2013). Chemotherapy-induced amenorrhea in patients with breast cancer with a BRCA1 or BRCA2 mutation. J. Clin. Oncol. 31, 3914-3919. doi: 10.1200/JCO.2012.47.7893

van Wagenen, G., and Simpson, M. E. (1965). Embryology of the Ovary and Testis in Homo sapiens and Macaca mulatta. New Haven, CT: Yale University Press.

Villaescusa, J. C., Allard, P., Carminati, E., Kontogiannea, M., Talarico, D., Blasi, F., et al. (2006). Clast4, the murine homologue of human eIF4ETransporter, is highly expressed in developing oocytes and post-translationally modified at meiotic maturation. Gene 367, 101-109. doi: 10.1016/j.gene.2005. 09.026

Wang, E. T., Pisarska, M. D., Bresee, C., Chen, Y. D., Lester, J., Afshar, Y., et al. (2014a). BRCA1 germline mutations may be associated with reduced ovarian reserve. Fertil. Steril. 102, 1723-1728. doi: 10.1016/j.fertnstert.2014.08.014
Wang, J., Zhang, W., Jiang, H., and Wu, B. L. (2014b). Mutations in HFM1 in recessive primary ovarian insufficiency. N. Eng. J. Med. 370, 972-974. doi: 10.1056/NEJMc1310150

Whitney, M. A., Royle, G., Low, M. J., Kelly, M. A., Axthelm, M. K., Reifsteck, C. et al. (1996). Germ cell defects and hematopoietic hypersensitivity to gammainterferon in mice with a targeted disruption of the Fanconi anemia $\mathrm{C}$ gene. Blood 88, 49-58.

Woad, K. J., Pearson, S. M., Harris, S. E., Gersak, K., and Shelling, A. N. (2009). Investigating the association between inhibin alpha gene promoter polymorphisms and premature ovarian failure. Fertil. Steril. 91, 62-66. doi: 10.1016/j.fertnstert.2007.11.012

Xu, H., Beasley, M. D., Warren, W. D., van der Horst, G. T., and McKay, M. J. (2005). Absence of mouse REC8 cohesin promotes synapsis of sister chromatids in meiosis. Dev. Cell 8, 949-961. doi: 10.1016/j.devcel.2005.03.018

Xu, S., Linher-Melville, K., Yang, B. B., Wu, D., and Li, J. (2011). Micro-RNA378 (miR-378) regulates ovarian estradiol production by targeting aromatase. Endocrinology 152, 3941-3951. doi: 10.1210/en.2011-1147

Xue, Y., Gao, X., Lindsell, C. E., Norton, C. R., Chang, B., Hicks, C., et al. (1999). Embryonic lethality and vascular defects in mice lacking the Notch ligand Jagged1. Hum. Mol. Genet. 8, 723-730. doi: 10.1093/hmg/8.5.723

Yan, C., Wang, P., DeMayo, J., DeMayo, F. J., Elvin, J. A., Carino, C., et al. (2001). Synergistic roles of bone morphogenetic protein 15 and growth differentiation factor 9 in ovarian function. Mol. Endocrinol. 15, 854-866. doi: 10.1210/mend.15.6.0662

Yang, J., Medvedev, S., Yu, J., Tang, L. C., Agno, J. E., Matzuk, M. M., et al. (2005). Absence of the DNA-/RNA- binding protein MSY2 results in male and female infertility. Proc. Natl. Acad. Sci. U.S.A. 102, 5755-5760. doi: 10.1073/pnas.0408718102

Yang, S., Wang, S., Luo, A., Ding, T., Lai, Z., Shen, W., et al. (2013). Expression patterns and regulatory functions of microRNAs during the initiation of primordial follicle development in the neonatal mouse ovary. Biol. Reprod. 89, 126. doi: 10.1095/biolreprod.113.107730

Yang, X., Zhou, Y., Peng, S., Wu, L., Lin, H. Y., Wang, S., et al. (2012). Differentially expressed plasma microRNAs in premature ovarian failure patients and the potential regulatory function of mir-23a in granulosa cell apoptosis. Reproduction 144, 235-244. doi: 10.1530/REP-11-0371

Yao, G., Yin, M., Lian, J., Tian, H., Liu, L., Li, X., et al. (2010a). MicroRNA-224 is involved in transforming growth factor- $\beta$-mediated mouse granulosa cell proliferation and granulosa cell function by targeting Smad4. Mol. Endocrinol. 24, 540-551. doi: 10.1210/me.2009-0432

Yao, N., Yang, B. Q., Liu, Y., Tan, X. Y., Lu, C. L., Yuan, X. H., et al. (2010b). Follicle-stimulating hormone regulation of microRNA expression on progesterone production in cultured rat granulosa cells. Endocrine 38, 158-166. doi: 10.1007/s12020-010-9345-1

Ying, Y., Liu, X. M., Marble, A., Lawson, K. A., and Zhao, G. Q. (2000). Requirement of Bmp8b for the generation of primordial germ cells in the mouse. Mol. Endocrinol. 14, 1053-1063. doi: 10.1210/mend.14.7.0479

Ying, Y., and Zhao, G. Q. (2001). Cooperation of endoderm-derived BMP2 and extraembryonic ectoderm-derived BMP4 in primordial germ cell generation in the mouse. Dev. Biol. 232, 484-492. doi: 10.1006/dbio.2001.0173

Yoon, S. H., Choi, Y. M., Hong, M. A., Lee, G. H., Kim, J. J., Im, H, J., et al. (2010). Estrogen receptor $\alpha$ gene polymorphisms in patients with idiopathic premature ovarian failure. Hum. Reprod. 25, 283-287. doi: 10.1093/humrep/dep375

Yu, J., Hecht, N. B., and Schultz, R. M. (2001). Expression of MSY2 in mouse oocytes and preimplantation embryos. Biol. Reprod. 65, 1260-1270. doi: 10.1095/biolreprod65.4.1260

Zamboni, L., Upadhyay, S., Bezard, J., Luciani, J. M., and Mauleon, P. (1980). "The role of the mesonephros in the development of the mammalian ovary," in Endocrine Physiopathology of the Ovary, eds R. I. Tozzini, G. Reeves, and R. L. Pineta (Amsterdam: Elsevier/North Holland Biomedical Press), $3-42$.

Zangen, D., Kaufman, Y., Zeligson, S., Perlberg, S., Fridman, H., Kanaan, M., et al. (2011). XX ovarian dysgenesis is caused by a PSMC3IP/HOP2 mutation that abolishes coactivation of estrogen-driven transcription. Am. J. Hum. Genet. 89, 572-579. doi: 10.1016/j.ajhg.2011.09.006

Zhang, F. P., Poutanen, M., Wilbertz, J., and Huhtaniemi, I. (2001). Normal prenatal but arrested postnatal sexual development of luteinizing hormone receptor knockout (LuRKO) mice. Mol. Endocrinol. 15, 172-183. doi: 10.1210/mend.15.1.0582 
Zhang, M., Su, Y. Q., Sugiura, K., Xia, G., and Eppig, J. J. (2010). Granulosa cell ligand NPPC and its receptor NPR2 maintain meiotic arrest in mouse oocytes. Science 330, 366-369. doi: 10.1126/science.1193573

Zhang, X. F., Zhang, T., Han, Z., Liu, J. C., Liu, Y. P., Ma, J. Y., et al. (2014). Transgenerational inheritance of ovarian development deficiency induced by maternal diethylhexyl phthalate exposure. Reprod. Fertil. Dev. doi: 10.1071/rd14113 [Epub ahead of print].

Zhang, X. M., Li, L., Xu, J. J., Wang, N., Liu, W. J., Lin, X. H., et al. (2013). Rapamycin preserves the follicle pool reserve and prolongs the ovarian lifespan of female rats via modulating mTOR activation and sirtuin expression. Gene 523, 82-87. doi: 10.1016/j.gene.2013.03.039

Zhao, H., Chen, Z. J., Qin, Y., Shi, Y., Wang, S., Choi, Y., et al. (2008). Transcription factor FIGLA is mutated in patients with premature ovarian failure. Am. J. Hum. Genet. 82, 1342-1348. doi: 10.1016/j.ajhg.2008.04.018

Zhao, H., Qin, Y., Kovanci, E., Simpson, J. L., Chen, Z. J., and Rajkovic, A. (2007). Analyses of GDF9 mutation in 100 Chinese women with premature ovarian failure. Fertil. Steril. 88, 1474-1476. doi: 10.1016/j.fertnstert.2007.01.021
Zhao, Z., Qin, Y., Ma, J., Zhao, H., Li, J., Wang, L., et al. (2011). PTEN gene analysis in premature ovarian failure patients. Acta Obstet. Gynecol. Scand. 90, 678-679. doi: $10.1111 / j .1600-0412.2011 .01118 . x$

Zhou, Y., Zhu, Y. Z., Zhang, S. H., Wang, H. M., Wang, S. Y., and Yang, X. K. (2011). MicroRNA expression profiles in premature ovarian failure patients and its potential regulate functions. Chin. J. Birth Health Hered. 19, 20-22.

Conflict of Interest Statement: The authors declare that the research was conducted in the absence of any commercial or financial relationships that could be construed as a potential conflict of interest.

Copyright $\odot 2015$ Pelosi, Forabosco and Schlessinger. This is an open-access article distributed under the terms of the Creative Commons Attribution License (CC BY). The use, distribution or reproduction in other forums is permitted, provided the original author(s) or licensor are credited and that the original publication in this journal is cited, in accordance with accepted academic practice. No use, distribution or reproduction is permitted which does not comply with these terms. 